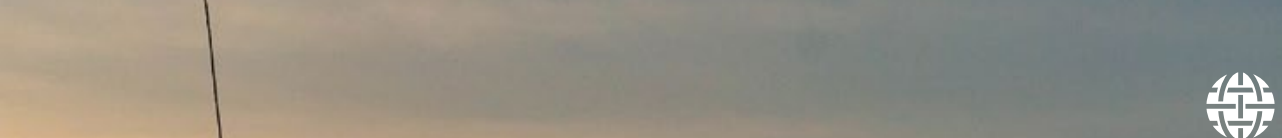

\title{
Atlantic Council
}

SCOWCROFT CENTER

FOR STRATEGY AND SECURITY
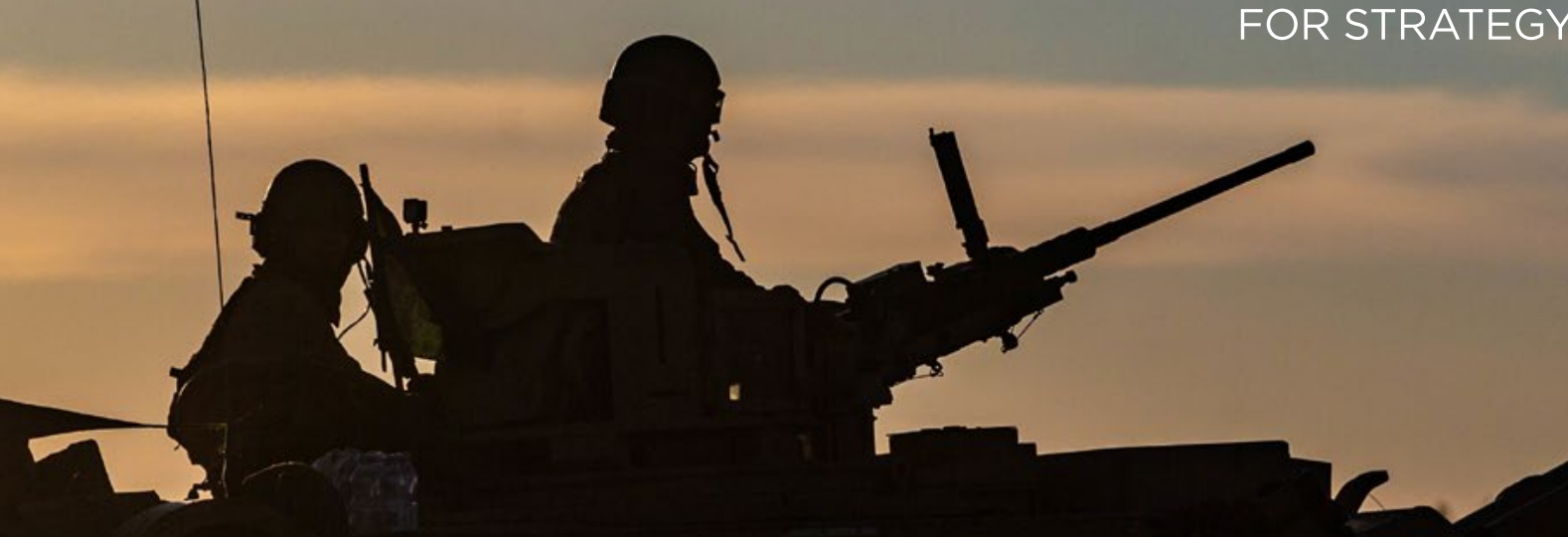


\section{Atlantic Council}

SCOWCROFT CENTER

FOR STRATEGY AND SECURITY

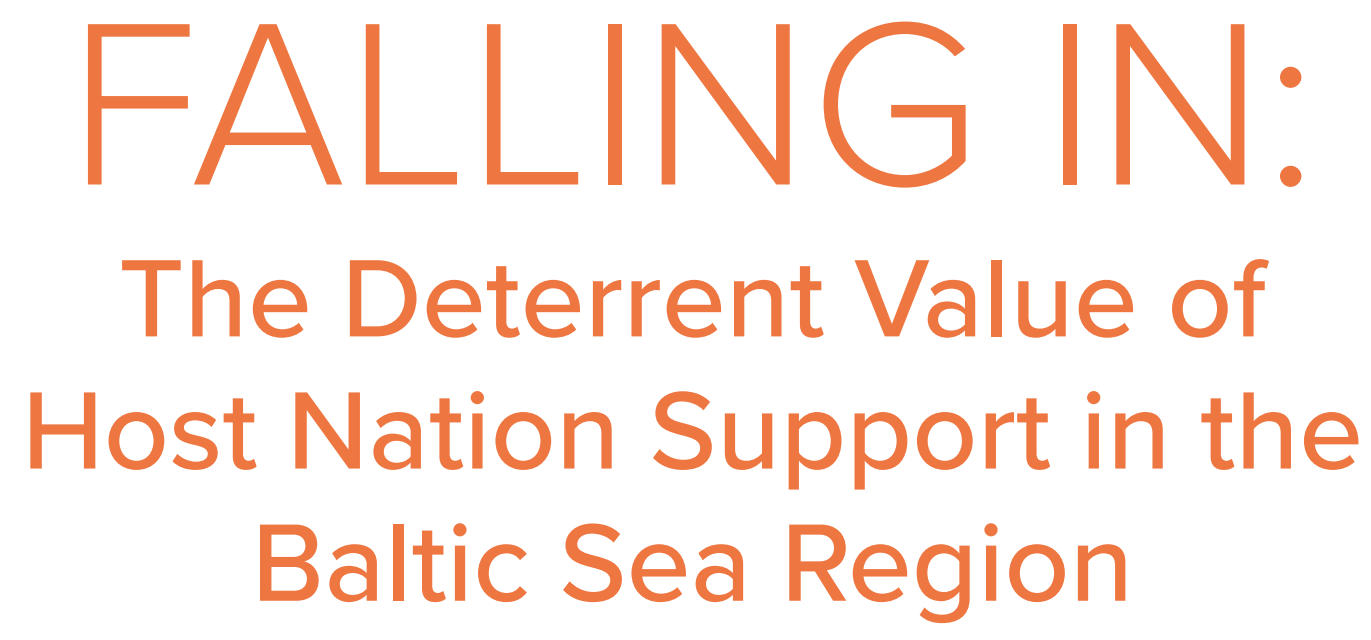

Kathleen J. Mclnnis and

Connor McPartland

Study and Editorial Director: Christopher Skaluba

Contributing Authors:

Clementine G. Starling and David Millner 
ISBN-13:978-1-61977-175-8

Cover: US Marines with 2nd Tank Battalion, 2nd Marine Division, II Marine Expeditionary, sits on a US Marine Corps M1A1 Abrams tank during exercise Arrow 2019 at the Pohjankangas Training Area near Niinisalo, Finland, May 15, 2019. Arrow 2019 is an annual multinational exercise with the purpose of training mechanized infantry, artillery, and mortar field skills in a live-fire exercise along with the partners from the Finnish Defense Forces. (US Marine Corps photo by Lance Cpl. Scott Jenkins)

This report is written and published in accordance with the Atlantic Council Policy on Intellectual Independence. The authors are solely responsible for its analysis and recommendations. The Atlantic Council and its donors do not determine, nor do they necessarily endorse or advocate for, any of this report's conclusions.

May 2021

(C) 2021 The Atlantic Council of the United States. All rights reserved. No part of this publication may be reproduced or transmitted in any form or by any means without permission in writing from the Atlantic Council, except in the case of brief quotations in news articles, critical articles, or reviews. Please direct inquiries to:

Atlantic Council, 1030 15th Street NW, 12th Floor, Washington, DC 20005 
The Scowcroft Center for Strategy and Security works to develop sustainable, nonpartisan strategies to address the most important security challenges facing the United States and the world. The Center honors General Brent Scowcroft's legacy of service and embodies his ethos of nonpartisan commitment to the cause of security, support for US leadership in cooperation with allies and partners, and dedication to the mentorship of the next generation of leaders.

The Scowcroft Center's Transatlantic Security Initiative brings together top policymakers, government and military officials, business leaders, and experts from Europe and North America to share insights, strengthen cooperation, and develop innovative approaches to the key challenges facing NATO and the transatlantic community. This publication was produced in partnership with the Lithuanian Ministry of National Defense under the auspices of a project focused on defense and deterrence in the Baltic Sea region and with additional support from Ambassador Colleen Bell. 


\section{TABLE OF CONTENTS}

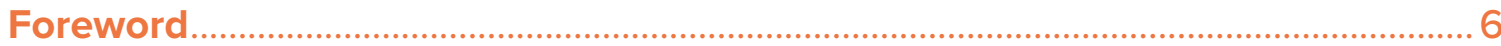

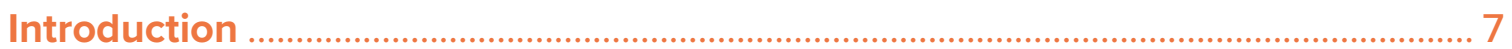

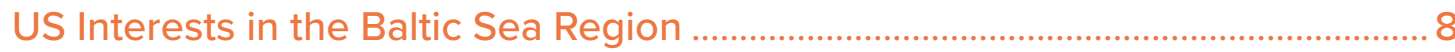

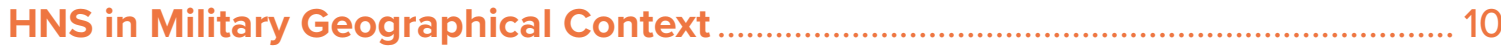

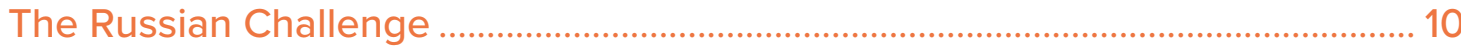

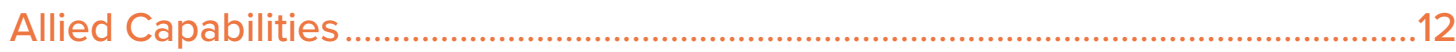

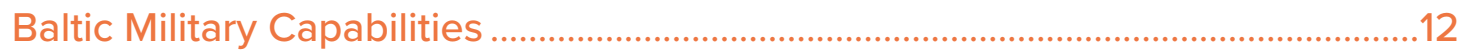

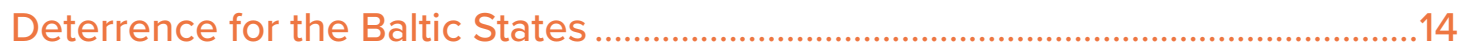

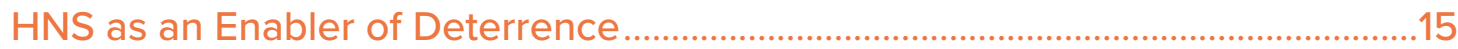

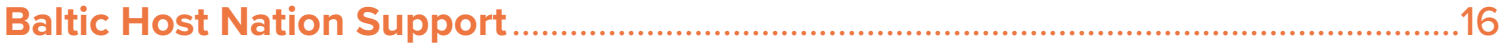

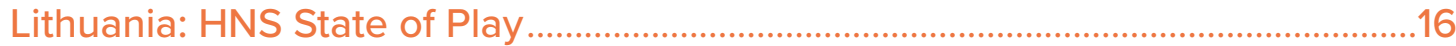

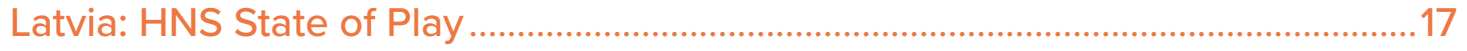

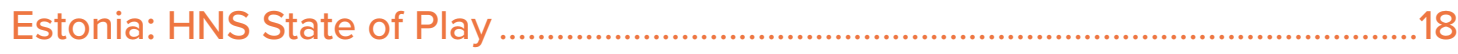

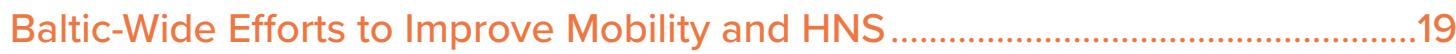

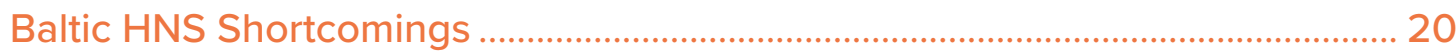

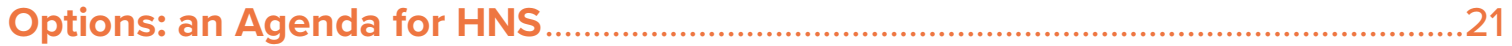

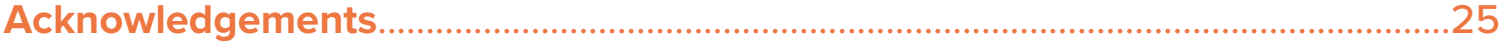

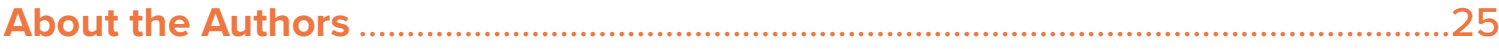




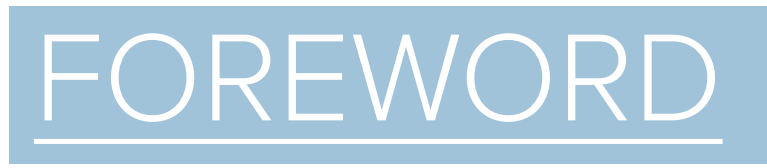

n early 2021 the world watched as Vladimir Putin's Russia once again used its military power to intimidate its neighbors, massing thousands of troops near the border with Ukraine. While the situation has not escalated as of the time of writing, Russia's continued aggressive behavior towards its neighbors should serve as a reminder that the security environment in Europe remains uncertain.

We thankfully haven't seen this kind of aggression against our allies in the Baltic states. Part of the reason for this is the security guarantee provided by NATO and reinforced by the efforts that the Baltic states and the Alliance have taken over the last several years to strengthen deterrence in the region. The Baltic states themselves have all made and continue to make tremendous investments in their own militaries, investing in key capabilities and expanding their armed forces. NATO has demonstrated its commitment by creating and exercising the Enhanced Forward Presence among other actions. Through the European Deterrence Initiative and Operation Atlantic Resolve the United States has also made significant contributions to the region including infrastructure investments and rotational troop deployments that serve as a reminder of the United States' commitment to its Allies.

The Atlantic Council has been at the forefront of the discussion around deterrence in northeastern Europe, providing US and allied policy makers with a wealth of analysis and recommendations to strengthen deterrence. In 2018-19, my predecessor as SACEUR, General Philip Breedlove, helped spearhead the report Permanent deterrence: Enhancements to the US military presence in North Central Europe which assessed the feasibility of an expanded US footprint in
Poland. Over 2019-20 I was honored to co-lead the Atlantic Council's Task Force on Military Mobility. Our report, Moving out: A comprehensive assessment of European military mobility, offers the most complete analysis of ongoing efforts to improve military mobility in Europe-an essential task for effective deterrence.

This new report, Falling in: The deterrent value of host nation support in the Baltic Sea region, picks up where Moving out left off-if Moving out was about moving forces from one end of Europe to the other, Falling in is about what those forces can expect to find once they get to the other side. The vital forward deployments of US and allied forces to the Baltic Sea region is only possible with the support of the receiving countries and Falling in highlights the often-overlooked importance of Host Nation Support to NATO's posture in the Baltic Sea region. This volume is a natural addition to the Scowcroft Center's series of reports on posture and deterrence in Europe and is an important contribution to those seeking detail on deterrence and defense in the Baltic states.

As the United States continues its global posture review this report should be a helpful reminder not only of the deterrent power of US forces but also of the efforts being made by key allies in enabling that deterrent presence. The future of deterrence in Europe is a team effort, and the support of our allies on the ground makes it all possible.

\section{General Curtis M. Scaparrotti, USA (Ret.)}

Former Supreme Allied Commander Europe, NATO Former Commander, United States European Command 


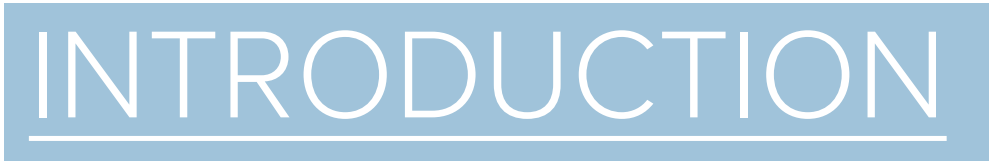

$\mathrm{N}$ ATO's founding premise, enshrined in Article 5 of the Washington Treaty, is one of collective defense: that an attack on one ally is an attack on all. ${ }^{1}$ Given the tensions and adversaries the Alliance has faced over its seventy-plus-year history, the fact that Article 5 has only been invoked once-after the September 11, 2001 attacks-arguably speaks to the impact that collective defense plays in the formulation and execution of credible transatlantic deterrence strategies. Yet, making deterrence work is not simply a matter of effective declaratory policy; it also requires careful, hard work.

In order to be credible, deterrence-generally thought of as a strategy designed to influence an actor not to do something it would otherwise do-must be backed up by investments in capabilities, exercises, and a dozen other important considerations. ${ }^{2}$ As the theory goes, the combination of NATO's demonstrated capabilities and declaratory policy around collective defense has been largely sufficient to deter significant aggression by an adversary against its members. During the Cold War, for example, NATO effectively deterred Soviet Union aggression against European member states through the protection of the US nuclear umbrella and large numbers of conventional forces stationed in Europe ready to counter Soviet maneuvers. This combination helped sustain an uneasy peace in Europe for more than forty years.

Since the end of the Cold War and the collapse of the Soviet Union, however, the security environment in Europe has drastically changed. NATO has expanded membership to thirty allies, including former Soviet and Warsaw Pact states. NATO's 2004 expansion brought the Baltic states of Estonia, Latvia, and Lithuania into the Alliance, all three having been formerly occupied by the Soviet Union. The addition of the Baltic states extended NATO's northern flank north and east to within one hundred and sixty kilometers of St. Petersburg, and through the gap between Russia's ally, Belarus, and Russia's heavily militarized exclave, Kaliningrad, on the Baltic Sea coast.

The implications of this extended flank became abundantly clear in 2014 after Russia's illegal invasion and annexation of Ukraine's Crimean Peninsula and subsequent (and ongoing) support for pro-Russia separatists in eastern Ukraine. The Baltic states-with their historic ties to Russia, sizable Russian minority populations, and relatively exposed position within NATO-were postured as potential next targets for a Russia looking to forcibly expand its sphere of influence and weaken the influence of NATO and the West along its border.

The renewed threat to NATO's territory, particularly in the small, exposed Baltic Sea region, revived focus on military deterrence in Europe. However, the geography of the Baltic states, the nature of the threat from Russia, and changes in overall NATO posture since the end of the Cold War mean the Alliance must think creatively about how to effectively deter-and, if necessary, defend against-Russian aggression. Moreover, given Russian interests in delegitimizing the Alliance, an attack on the Baltics is generally interpreted as one of Moscow's favored tactics to undermine solidarity in the West and disprove the idea of collective defense altogether. This makes deterrence of Russian aggression in the region not only a matter of territorial integrity and collective security, but also a fundamental requirement for ensuring NATO-and, by extension, Western values-remains inviolable.

To adequately ensure that deterrence is credibly capable of denying Russia victory in the region, without imposing unacceptable costs on its member states (not least the Baltics themselves), the Alliance needed a new model that takes the distinctive features of the Baltic states into account. The model that has emerged is one of deterrence primarily through the credible threat of rapid reinforcement of Baltic allies, with three linchpins: national forces, forward-deployed NATO and US units, and the ability to rapidly reinforce these forward units with additional forces from elsewhere in Europe and North America. ${ }^{3}$

While newspaper headlines and think-tank publications often suggest analyzing NATO deterrence in the Baltic states in terms of raw firepower-how many tanks, how many surfaceto-air missiles, how many soldiers are present in the regionthe role of support from the Baltic states themselves is often overlooked. This Host Nation Support (HNS) underpins allied presence and, though difficult to quantify, has independent deterrent value as well. Without adequate HNS, all of the other elements contributing to NATO defense and deterrence in the Baltic states are not viable. In this case, NATO's strategy

\footnotetext{
"The North Atlantic Treaty," North Atlantic Treaty Organization, April 4, 1949, https://www.nato.int/cps/en/natolive/official_texts_17120.htm. David Kinsella, Bruce Russett, and Harvey Starr, World Politics: The Menu for Choice (Boston, MA: Wadsworth Cengage, 2013), 71.

For more in-depth discussions of the makeup of deterrence in the Baltic Sea region and Northeastern Europe, see: Jonatan Vseviov, "Constructing Deterrence in the Baltic States," International Centre for Defence and Security, February 2021, https://icds.ee/wp-content/uploads/2021/02/ICDS_Analysis_ Constructing_Deterrence_in_the_Baltic_States_Jonatan_Vseviov_February_2021-1.pdf; Hans Binnendijk and Conor Rodihan, Geometries of Deterrence: Assessing Defense Arrangements in Europe's Northeast, Atlantic Council, May 2020, https://www.atlanticcouncil.org/wp-content/uploads/2020/05/ Geometries-of-Deterrence-Report-Web.pdf.
} 

in the Baltic Sea region. In light of the changing security environment in Europe after 2014, the United States has taken a more active role in helping to establish deterrence in the Baltic states. However, the underlying reasons for why the United States cares about what happens in Europe generally, and the Baltic states specifically, may have become less clear, particularly in the decades after the end of the Cold War. The US taxpayer might, therefore, be forgiven for asking why the United States should care about the Baltic states-a small corner of the world far away from US shores.

The answer lies in the critical importance that NATO has for the simultaneous advancement of both US and European interests. The bedrock of NATO is a collective-defense provision that was codified in Article 5 of NATO's founding document, the 1949 Washington Treaty. Although the US security guarantee for its NATO allies has been at the heart of the Alliance's political-military framework, and the United States has spent considerable sums on the maintenance of defense capabilities to support that guarantee, it should be noted that this has by no means been a one-way bargain. These treaty relationships have afforded the United States a position of strategic leadership and depth. As a result of the central US role in transatlantic and international relations that NATO has in many ways cemented, Americans have enjoyed unprecedented economic prosperity and freedom. Successive US governments have been afforded both de facto and de jure privileged status when it has come to issues including trade partnerships and access to bases, in large part, because of the outsized role that the United States plays in the defense of its allies. ${ }^{6}$

Beyond a favorable military posture, the United States finds itself in a comparatively advantageous situation with respect to arms sales, technology transfers, and other key commercial and economic relationships that have enabled the United States' role as security guarantor. Additionally, the United States is able to exercise strategic leadership and set the agenda for responding to emerging challenges of national import like migration, terrorism, and pandemic health emergencies through the collective and consultative process afforded by the NATO Alliance. Alone, the United States would be less flexible and, therefore, less effective.

For example, the United States would have found it much more difficult to prosecute expeditionary and counterterrorism operations in the Middle East and Africa were it not for the bases and prepositioned equipment that it has been able to maintain on allied soil in Europe. Coalition operations to stabilize the Balkans or conduct anti-piracy missions off the Horn of Africa would not be as comparatively straightforward (or even possible) without the NATO International Military Staff, through which allies can collectively plan for and integrate military operations.

Another long-standing reason for US engagement in the European theater generally, and the Baltic states specifically, is to enable US strategic depth. Labelled "defense in depth" by security practitioners, as the logic went at the end of World War II and the subsequent initiation of the Cold War, military technological developments and adversary operations during the world wars demonstrated that the United States was no longer sufficiently protected by the two oceans abutting its shores. ${ }^{7}$ As a result, it was deemed strategically prudent to station US forces overseas in order to be able to contend with adversary aggression-if not outright conflict-far away from the US homeland. Not only did this make the US homeland less vulnerable to outright war, but forward presence was also viewed as relatively cost-effective compared to war on the North American continent.

Even as the Cold War ended and the strategic context for US military involvement internationally changed, the rationale of defense in depth has endured. For example, a primary goal of US counterterrorism operations in the Middle East after the September 11, 2001 attacks was to tackle the root sources of violent extremist groups before they could again build sufficient capability and capacity to conduct terrorist attacks against the US homeland. Notably, US bases and presence in Europe are vital to enabling US operations in the Middle East and Africa. ${ }^{8}$ This strategic depth continues to allow the United States to exercise strategic leadership globally, and to counter crises in the European theater emanating from a revanchist Russia. This forward posture and the NATO Alliance allow options for defending the Alliance and its own interests in a relatively affordable and lower-risk manner than might otherwise be possible without posture in the European theater.

Strategic leadership and depth are why the NATO Alliance's value is difficult to overstate. It is a political-military arrangement that is wholly unique in human history, and has consistently demonstrated its many advantages to its members. ${ }^{9}$ In the face of Moscow's strategic interests in the Baltic region, shoring up NATO and ensuring its enduring strategic capability and credibility is a matter of national interest to allies on both sides of the Atlantic.

\footnotetext{
6 This builds off of Glenn Snyder's points about alliances having a "political penumbra." Glenn H. Snyder, Alliance Politics (Ithaca, NY: Cornell University Press, 2007.).

Stacie Pettyjohn, U.S. Global Defense Posture, 1783-2011 (Arlington, VA: RAND, 2012).

8 Luke Coffey, "Keeping America Safe: Why U.S. Bases in Europe Remain Vital," Heritage Foundation, July 11, 2012, https://www.heritage.org/defense/report/ keeping-america-safe-why-us-bases-europe-remain-vital.

9 Mira Rapp-Hooper, Shields of the Republic: The Triumph and Peril of America's Alliances (Cambridge, MA: Harvard University Press, 2020).
} 


\section{HNS IN MILITARY}

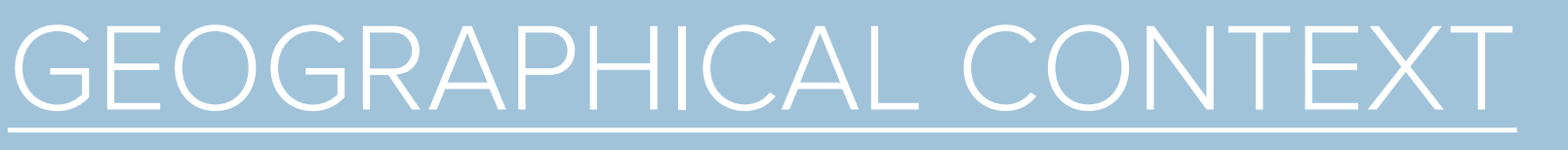

W hile HNS is often analyzed in tactical terms, the strategic implications of HNS-in the Baltic Sea region in particular-are profound. The complex security challenge posed by Russia, combined with the particular geography of the region and the relatively limited resources of Baltic national defense budgets, means that HNS plays an outsized role in enabling NATO's overall deterrence strategy in the region. To understand why HNS is such a critical aspect of deterrence in the Baltic states, it is useful to recall the specific challenges facing Estonia, Latvia, and Lithuania and how the three Baltic states, their allies in NATO, and the United States are approaching defense of the region.

\section{THE RUSSIAN CHALLENGE}

\section{Russia's Interests in the Baltic States}

Russia's 2014 invasion and annexation of Crimea, and its subsequent support for separatist forces in the Donbass region of eastern Ukraine, were a wake-up call for many in NATO; the relative security and strategic stability that Europe had enjoyed since the end of the Cold War could no longer be taken for granted. While many Western allies were shocked by Russia's actions, they came as no surprise to the three Baltic states-Lithuania, Latvia, and Estonia-who, along with Poland, had been sounding the alarm in NATO circles about Russia's malign intentions for years. ${ }^{10}$ Three main factors drive this concern. First is the Baltic region's historic relationship with Russia. Lithuanian, Latvian, and Estonian territory was all part of the Russian Empire from at least the eighteenth century through the end of World War I. After a brief period of independence during the interwar period, all three states were occupied by the Soviet Union at the outset of World War II, and again at the end, until regaining independence in 1991.
The countries' long history of occupation or control by Moscow means that there are many still in Russia who see the Baltic states as lost Russian territory or, at the very least, as historic members of Russia's sphere of influence."

This long history of occupation by Russia has led to the second factor for concern, a sizeable Russian-speaking minority, mostly concentrated in Estonia and Latvia. Thirty percent of Estonians and 34 percent of Latvians speak Russian as a first language, with a smaller proportion of Lithuanians being of Russian descent or having Russian as a mother tongue. ${ }^{12}$ This has caused concerns that Russia might invoke its so-called "compatriot policy," which posits that Russia has a duty to protect Russian speakers outside of Russia. ${ }^{3}$ The policy was used to justify Russia's invasion and annexation of Crimea, and some worry that Russia could again use it as a basis for "protecting" Russian speakers against alleged mistreatment in the Baltic states. ${ }^{14}$

Lastly, the Baltic states could find themselves under threat as Russia tries to achieve its political goal of undercutting the credibility of NATO. Since the end of the Cold War, Russia has been unnerved by NATO's expansion up to its own borders, and portrays itself as threatened by Western encroachment. ${ }^{15}$ Scholars and policymakers have argued that Russia may take advantage of the Baltic states' small size and relative geographic isolation from their allies to foment a crisiseither through small, hybrid actions or conventional military means-to seize territory outright or test NATO's commitment to collective defense. Within these scenarios, either a real or perceived failure on NATO's part to effectively respond to such aggression would thereby remove the Alliance as a credible military threat. ${ }^{16}$ Discrediting the United States and NATO could lead to transatlantic strategic insolvency: a situation whereby allies, including the United States, are unable to meet their

10 Stephen F. Larrabee, et al., "Russia and the West After the Ukrainian Crisis: European Vulnerabilities to Russian Pressures," RAND, 2017, https://www.rand.org/ content/dam/rand/pubs/research_reports/RR1300/RR1305/RAND_RR1305.pdf.

11 Agnia Grigas, "Legacies, Coercion and Soft Power: Russian Influence in the Baltic States," Chatham House, August 2012, https://www.academia. edu/3120427/Legacies_Coercion_and_Soft_Power_Russian_Influence_in_the_Baltic_States.

12 Una Bergmane, "Fading Russian Influence in the Baltic States," Orbis, 2020, 484, https://www.ncbi.nlm.nih.gov/pmc/articles/PMC7329289/pdf/main.pdf. Ibid., 484 .

ibid., 484-486.

James Milano, "NATO Enlargement From The Russian Perspective," US Army War College, February 5, 1998, https://www.hsdl.org/?view\&amp;did=453037.

David A. Shlapak and Michael Johnson, "Reinforcing Deterrence on NATO's Eastern Flank: Wargaming the Defense of the Baltics," RAND, 2016, https://www. rand.org/pubs/research_reports/RR1253.html; Franklin D. Kramer and Lauren M. Speranza, Meeting the Russian Hybrid Challenge, Atlantic Council, May 30 , 2017, https://www.atlanticcouncil.org/wp-content/uploads/2017/05/Meeting_the_Russian_Hybrid_Challenge_web_0530.pdf. 
security obligations to, or achieve favorable standards of living for, their populations. It follows, therefore, that shoring up NATO and ensuring its enduring strategic capability and credibility are matters of national interest to allies on both sides of the Atlantic.

\section{Russian Conventional Capabilities}

On the basis of any of the reasons mentioned above, Russia may someday feel that aggression against the Baltics, specifically a surprise attack, would serve its political aims to undermine NATO_especially on Russia's border. Should a crisis break out, Russia possesses formidable capabilities in the Baltic neighborhood that could seriously threaten Estonia, Latvia, and Lithuania. The unique geography of the Baltic Sea region poses a number of defense challenges for NATO in the land and maritime domains, and Russia's military buildup in the region is uniquely designed to complicate NATO defense of the Baltic allies. While only Estonia and Latvia border mainland Russia, Lithuania is bordered by Belarus and Kaliningrad, Russia's ally and heavily militarized exclave, respectively. Furthermore, the Baltics' small geography and restricted land connection to the rest of NATO through the Suwalki Gap-a thin, sixty-mile corridor of land that connects Poland and Lithuania-complicate their defense from Russian conventional capabilities.

While NATO member states globally outmatch Russia in conventional military force, Moscow maintains a regional force advantage and is able to severely complicate NATO's ability to operate in the Baltic Sea region. The Baltic states border Russia's Western Military District, which "fields the most robust, most numerous, and most capable fighting forces" of Russia's five military districts and commands. ${ }^{17}$ The 6th Combined Arms Army is stationed in the Baltic region and consists of nine regiments and brigades, including two tank battalions. ${ }^{18}$ Perhaps the most daunting challenge for NATO is Russia's extensive anti-access/area denial (A2/AD) network of missiles and airpower, which threatens to create a defensive bubble over the Baltic Sea region that NATO airpower could struggle to penetrate. This network includes the S-400, S-300PM, and S-300 PS surface-to-air missile batteries of the 6th Air and Air Defense Army headquartered in St. Petersburg and the K-300 Bastion-P coastal-defense system and six battalions of S-400 missiles in the heavily militarized Kaliningrad Oblast. ${ }^{19}$ Iskander surface-to-surface ballistic missiles and Kalibr land-attack cruise missiles also threaten allied ground forces as far away as Denmark, and could disrupt reinforcement of the region. ${ }^{20}$

Kaliningrad is also home to the Russian Baltic Fleet, which, while not the strongest of Russia's fleets, could still threaten allied reinforcements arriving by sea. Aviation and Russian Ground Forces units in Kaliningrad present a challenge to any NATO forces attempting to reinforce the Baltic states by land.

\section{Baltic Sea Region Active Duty Forces by Country}

\section{National Forces —uS Forces — NATO eFP — Russia (Western Military District)}

\section{Russia}

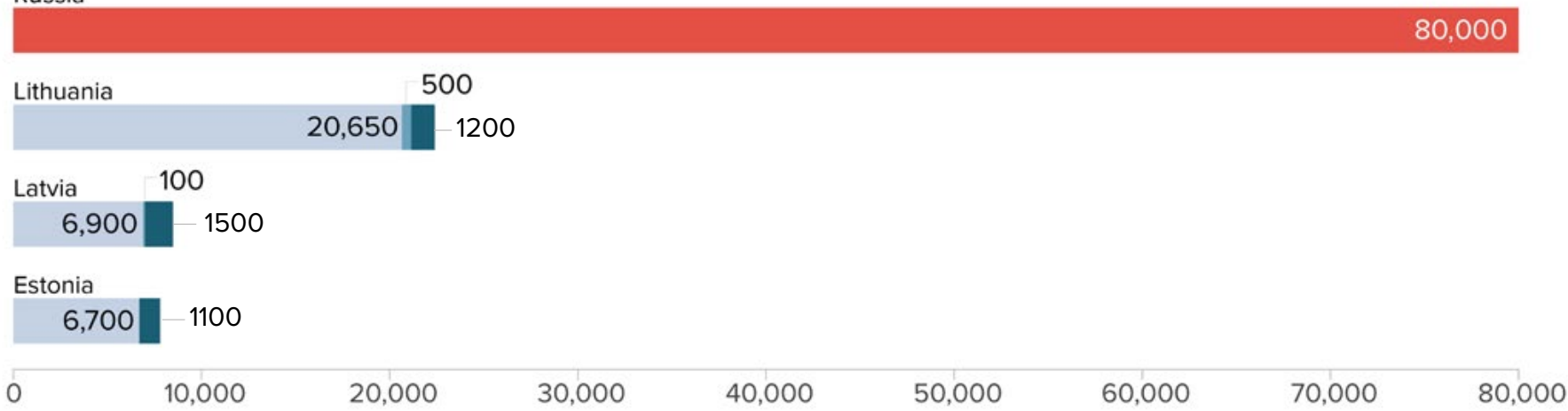

Data presented in this chart was collected from the following sources: Hans Binnendijk and Conor Rodihan, Geometries of Deterrence: Assessing Defense Arrangements in Europe's Northeast, Atlantic Council, May 2020, https://www.atlanticcouncil.org/wp-content/uploads/2020/05/Geometriesof-Deterrence-Report-Web.pdf; "The Military Balance,," International Institute for Strategic Studies, 2020, 64-165.

7 Konrad Muzyka, "Russian Forces in the Western Military District," CNA, December 2020, 4, https://www.cna.org/CNA_files/PDF/IOP-2020-U-028759-Final. pdf.

18 Ibid., 18-19.

19 Ibid., 50

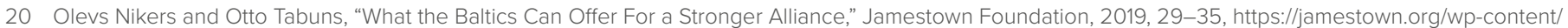
uploads/2019/09/Baltic-Security-Strategy-Report-2019.pdf?×94108\#page=64. 


\section{Russian Hybrid Capabilities}

In addition to the conventional forces arrayed near the Baltic states, Russia maintains and employs a variety of hybrid tactics to maintain pressure and assert intimidation against the Baltic states. Russian hybrid activities involve "the use of assertive policies, information operations, and covert and overt military and nonmilitary tactics (including cyberattacks)."21 A key element of Russia's strategy is to execute activities below the threshold of a conventional attack, in order to ensure they remain unlikely to trigger a conventional response from NATO and are intentionally ambiguous to muddle any unified NATO response. Russia has historically used proxies, propaganda, cyberattacks, and other means to foment pro-Russian protests and instability in the Baltics, and its attacks have evolved over time. ${ }^{22}$

\section{Allied Capabilities}

Since joining NATO in 2004, the Baltic states have emerged as some of the Alliance's most reliable and capable allies. All three spend the NATO goal of 2 percent of gross domestic product (GDP) on defense, and all have invested significantly in improving and modernizing their forces. ${ }^{23}$ However, the Baltic states' geographic position and small size mean that they remain vulnerable to Russian aggression. All three states' defense strategies are built around territorial defense and include NATO membership as the cornerstone of their security.

\section{Baltic Military Capabilities}

Lithuania's armed forces are the largest in the region, with nearly twenty-one thousand active-duty troops. The Lithuanian Land Forces are organized into one mechanized infantry brigade ("Iron Wolf") and one motorized infantry brigade ("Griffin"), with a third light-infantry brigade made up of reserves and training command personnel able to be activated in wartime. Lithuania's navy is typical for the region, being made up mostly of coastal-patrol and mine-warfare vessels. The air force is also small, with one air-defense battalion and twelve transport and searchand-rescue planes and helicopters. Lithuania has invested significantly in recent years to modernize its forces, acquiring new infantry fighting vehicles, self-propelled artillery, and Black Hawk helicopters. ${ }^{24}$
The Latvian military has 6,900 active-duty personnel, with one mechanized infantry brigade in the Latvian Land Forces, which are supported by 7,500 part-time National Guard personnel. Like those of Lithuania and Estonia, the Latvian Navy consists of mine-warfare and coastal-patrol ships. The Latvian Air Force includes an air-defense battalion, transport squadron, and radar squadron. ${ }^{25}$

At the northern end of the Baltic states, Estonia fields a military with 6,700 active-duty personnel. The Estonian Land Forces are organized into one mechanized and one light-infantry brigade, each with artillery and anti-tank and anti-air capabilities. Land Forces are augmented by 15,800 members of the volunteer Defense League. The Estonian Navy is built around four minewarfare vessels and the Estonian Air Force is made up of one fixed-wing and one helicopter-transport squadron. ${ }^{26}$

To augment their relatively small conventional militaries, all three of the Baltic states employ some type of "total defense" concept and make use of large volunteer, reserve, or paramilitary organizations. Lithuania sports the twelvethousand-strong paramilitary Riflemen's Union, which provides military-style training for civilians, and would support the regular military in defending Lithuanian territory. ${ }^{27}$ In Estonia, 15,800 members of the Defense League are available to support the military in territorial defense. ${ }^{28}$ Latvia relies on a large reserve component $(10,500)$ and its National Guard $(7,500)$ to augment its active-duty forces. Both Estonia and Lithuania also maintain conscription, giving them a steady supply of new recruits and reservists. ${ }^{29}$ To counter Russian hybrid threats, all three Baltic states maintain robust cybersecurity and counter disinformation systems. Lithuania manages its cybersecurity through the National Cyber Security Center, and Latvia and Estonia both host NATO Centers of Excellence focused on hybrid and cyber threats-the Strategic Communications Centre of Excellence in Riga and the Cooperative Cyber Defense Centre of Excellence in Tallinn.

Despite all three Baltic countries spending more than 2 percent of their GDP on defense, the countries' comparatively small economies mean that many high-level, and often expensive, capabilities remain out of reach. In recent years, all three states have invested in necessary capabilities, including infantry fighting vehicles, self-propelled artillery, and anti-tank missile systems. Still, for vital high-end capabilities like main

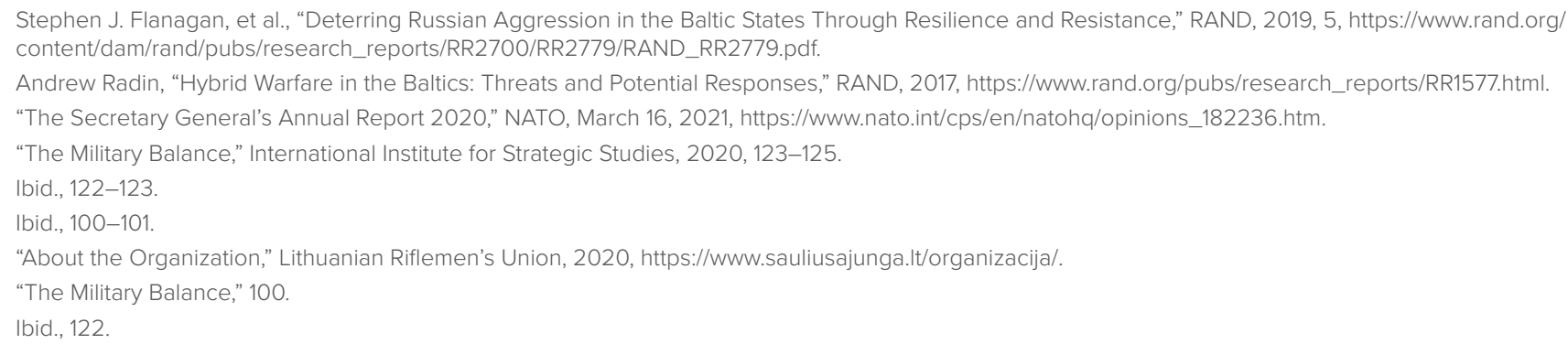


battle tanks and fighter aircraft, the Baltic states remain reliant on their NATO allies. As a result, HNS plays an especially important role in the national security architecture of each of the Baltic states.

\section{NATO in the Baltic Sea Region}

After Russia's 2014 invasion and annexation of Crimea, and its subsequent military materiel and personnel support for separatists in eastern Ukraine, NATO launched the Enhanced Forward Presence mission (eFP), under which multinational battlegroups deploy to each of the three NATO Baltic states and Poland, to surge military capabilities to the region and bolster deterrence against Russian aggression. Each roughly battalion-sized battlegroup is led by a "framework nation" and is incorporated into a host-nation unit. The battlegroups provide capabilities missing from national arsenals in the Baltic states, most notably main battle tanks. Twenty allies contribute forces to the eFP battlegroups, with the United States, Germany, Canada, and the United Kingdom serving as framework nations in Poland, Lithuania, Latvia, and Estonia, respectively. ${ }^{30}$

After 2014, NATO also expanded its Baltic Air Policing Mission, which has provided fighter-aircraft patrols over the Baltic states since 2004 . Fighters provided by allies on a rotating basis fly out of Šiauliai in Lithuania and, since 2014, from Ämari in Estonia. Deployments consist of about four fighter aircraft at each base, deployed on four-month rotations, to enable persistent NATO presence in Baltic airspace.

\section{US Military Presence in the Baltic Sea Region}

Russian action in Ukraine underscored to policymakers on both sides of the Atlantic that Russia was no longer interested in being a partner in European security and stability. Quite the opposite; Russia had demonstrated its capability and willingness to opportunistically redraw national European borders. As a result, deterring further aggression in Europe, particularly against NATO allies, became a key focus for the Alliance. ${ }^{31}$

In order to meet increased demands, the United States established the European Deterrence Initiative (EDI) (formerly the European Reassurance Initiative) and Operation Atlantic
Resolve. The former is the funding mechanism for the latter. Under this rubric, the United States invested in modernizing its infrastructure and training, among other things, to enhance the US ability to rapidly reinforce European allies in the event of a crisis on the European continent. Approximately \$4-6 billion has been allocated annually toward that mission since $2014 .{ }^{32}$

The United States and NATO allies have made significant posture adjustments in the European theater since 2014, and this study was also conducted in the context of enormous, unilateral force-posture decisions by the United States in mid2020. During the spring and summer of 2020, then-Secretary of Defense Mark Esper proposed a number of changes to the US footprint in Europe, including consolidation of key headquarters, the return of 6,400 troops to the continental United States, and the repositioning of a further 5,600 personnel from Germany to other countries in Europe. As was noted at the time:

The plan will consolidate headquarters to strengthen operational efficiency, will reposition some forces to the United States to focus on readiness, and place rotational forces in the Black Sea region on NATO's southeastern flank. ${ }^{33}$

Though the new US administration has since announced a global posture review and frozen decisions of the Donald Trump administration, including all planning for the withdrawal of forces from Germany, the debate poses important questions for NATO, US, and Baltic defense planners with respect to future posture in the region. The United States concluded bilateral defensecooperation agreements (DCAs) -an important and necessary step to enable an increased footprint on the ground-with each of the three Baltic states in 2017, following the Russian aggression against Ukraine in 2014. The DCAs provide a legal framework and details for US presence in the region. In 2019, these DCAs were augmented with bilateral defense-cooperation roadmaps that set further goals for defense cooperation in the 2019-2024 timeframe. ${ }^{34}$ Separate, but related, the United States concluded a bilateral DCA with Poland in late summer 2020, which provides a legal framework and burden-sharing details for US forces in Poland. Accordingly, US Army V Corps will maintain a rotating headquarters in Poland, in addition to other capabilities and forces.

30 “NATO's Enhanced Forward Presence: Fact Sheet," NATO, October 2019, https://www.nato.int/nato_static_fl2014/assets/pdf/pdf_2019_10/20191024_1910factsheet_efp_en.pdf.

31 John R Deni, Disband the NATO Response Force-NATO 20/2020, At/antic Council, October 14, 2020, https://www.atlanticcouncil.org/content-series/ nato20-2020/disband-the-nato-response-force/.

32 Paul Belkin, "The European Deterrence Initiative: A Budgetary Overview," Congressional Research Service, https://fas.org/sgp/crs/natsec/IF10946.pdf.

33 "Department of Defense Statement: US European Command Force Posture Review," US Department of Defense, last updated July 29, 2020, https://www. defense.gov/Newsroom/Releases/Release/Article/2292244/department-of-defense-statement-us-european-command-force-posture-review/.

34 "U.S. Security Cooperation with the Baltic States," United States Department of State, January 20, 2021, https://www.state.gov/u-s-security-cooperation-withthe-baltic-states/\#: : :text=In\%202017\%2C\%20the\%20United\%20States,Estonia\%2C\%20Latvia\%2C\%20and\%20Lithuania.\&amp;text=In\%202019\%2C\%20 the\%20United\%20States,cooperation\%20priorities\%20for\%202019\%2D2024. 
As mentioned above, the United States serves as the framework nation of the NATO eFP battlegroup in Poland. Eight hundred and fifty-seven troops lead the battlegroup on a rotational basis as part of an armored battalion. US aircraft also take part in Baltic Air Policing rotations, most recently contributing four F-15Cs in Lithuania in 2017. ${ }^{35}$ While US forces make up the majority of Poland's eFP battlegroup, these contributions do not make up a majority of US forces in the region. Nearly four thousand additional US troops are deployed on regular rotations through Poland as part of Operation Atlantic Resolve-part of the US European Deterrence Initiative-and NATO missiledefense missions.

Elements of US forces on deployment as part of Operation Atlantic Resolve frequently deploy for bilateral and multilateral training in the Baltic states. During 2020, Lithuania hosted two armored battalions-1st Battalion, 9th Cavalry Regiment from October 2019 to May 2020, and 2nd Battalion, 69th Armor Regiment from September until November 2020. ${ }^{36}$ A third armored battalion was deployed to Lithuania in November 2020, and will stay until June 2021. ${ }^{37}$ Elsewhere in the Baltic Sea region, as part of Operation Atlantic Resolve's aviation rotations, ten US Black Hawk helicopters and crews from the 101st Combat Aviation Brigade are deployed at Lielvārde in Latvia on a nine-month rotation. ${ }^{38}$

\section{DETERRENCE FOR THE BALTIC STATES}

The above discussion of the Baltics' geographical proximity to Russia, the overlapping patchwork of political and defense ties among the states in the region, the significant $A 2 / A D$ challenge presented by Russia's disposition in Kaliningrad and the Baltic Sea, and Moscow's attempted utilization of unconventional-warfare techniques to achieve its objectives make defense of the Baltic states uniquely challenging, but also uniquely critical to US and transatlantic security. Due to their small size, the Baltic states all have similar capability gaps in their national forces. None of the three countries possess its own main battle tanks, and all rely on NATO eFP forces for this capability on their territory. Similarly, long-range fires and air-defense systems remain key areas of need.
The particular geometries of the Baltic Sea region present a conundrum for allied planners: how can NATO ensure credible and capable deterrence in such a compact region where local forces are overmatched by their potential adversary? As conveyed by former Estonian Ambassador to the United States Jonatan Vseviov in a recent International Centre for Defence and Security (ICDS) paper, the solution comes in three parts.

First, national forces in the three Baltic states must be capable of responding to Russian aggression, communicating a local resolve to resist that aggression. Second, forward-deployed allied forces, either through eFP or bilaterally agreed deployments, guarantee that aggression from Russia will be met with a multinational response involving several NATO allies from beyond the Baltic Sea region. These forward forces also augment the capabilities of the local Baltic forces reinforcing the ability of forces in the region to adequately respond to Russian actions. Third, and most importantly, deterrence relies upon rapid reinforcement to the region in order to "conduct a wider operation to deny gains and impose unacceptable costs on the aggressor."39

In order for this strategy to be effective, all three of these interconnected parts must be in place and capable of carrying out their role in the strategy. For the last two pieces of the strategy-forward-deployed allied forces and rapid reinforcement-effective execution is impossible without adequate HNS from the Baltic states. HNS must enable the positioning and sustainment of forward-deployed allied troops, help them to maintain readiness, and prepare them for potential crisis response in the Baltic region. HNS must also be able to shepherd large flows of allied forces in the case of a crisis, including effectively assisting in their reception, staging, and onward movement.

The Baltic states have recognized the criticality of HNS and, in the last decade, have undertaken several initiatives to improve their ability to host and receive the allied forces necessary for establishing credible and capable deterrence in the region. The next section details how the Baltic states have worked to improve their HNS in key areas, and how those efforts contribute to deterrence.

35 "US Air Force Assumes Lead of 45th Rotation of Baltic Air Policing," NATO, 2017, https://ac.nato.int/archive/2017/us-air-force-assumes-lead-of-45th-rotation-ofbaltic-air-policing

36 "Gratitude Expressed to Outgoing US Rotation," Lithuanian Armed Forces, May 21, 2020, https://kariuomene.kam.lt/en/military_insignia/news_1889/ gratitude_expressed_to_outgoing_._US_rotation.html?pbck=0; "Another US Battalion Set to Arrive in Lithuania for Six Months in November-Ministry," Baltic Times, September 22, 2020, https://www.baltictimes.com/another_us_battalion_set_to_arrive_in_lithuania_for_six_months_in_november__ministry/.

37 "Gratitude Expressed to Outgoing US Rotation."

38 "New flock of US Black Hawk helicopters rotates into Latvia," Latvian Public Broadcasting, July 13, 2020, https://eng.Ism.Iv/article/society/defense/new-flockof-us-black-hawk-helicopters-rotates-into-latvia.a366971/.

39 Jonatan Vseviov, "Constructing Deterrence in the Baltic States," International Centre for Defence and Security, February 2021, https://icds.ee/wp-content/ uploads/2021/02/ICDS_Analysis_Constructing_Deterrence_in_the_Baltic_States_Jonatan_Vseviov_February_2021-1.pdf. 


\section{HNS as an Enabler of Deterrence}

The HNS needed to support and sustain persistent allied presence and high-end capabilities in the Baltic Sea region is only one piece of the deterrence puzzle. Even though US and allied air and land capabilities deployed to the region are substantial, they alone are not enough to defend against largescale or persistent Russian military aggression against the Baltic states. Russia holds a local force overmatch against NATO, necessitating a strategy of rapid reinforcement-being able to quickly surge allied forces to the region in the event of a crisisto credibly deter aggression.

While NATO has not made any doctrinal pronouncements per se, actions taken by the Alliance since 2014 demonstrate that rapid reinforcement is at the core of NATO's deterrence strategy.
After Russia's illegal annexation of Crimea, NATO enlarged the NATO Response Force (NRF), the Alliance's designated rapidreaction force, from fifteen thousand to forty thousand troops. And, from within the NRF, it designated the Very High Readiness Joint Task Force (VJTF), a five-thousand-strong land force with necessary enablers, able to respond to a crisis within two to seven days, with follow-on forces expected in around thirty days. ${ }^{40}$ These initial actions were reinforced at the 2018 Brussels Summit, where NATO approved the NATO Readiness Initiative, also known as the "four thirties," which aims to designate thirty battalions, thirty air squadrons, and thirty combat ships to be ready for deployment within thirty days' notice. ${ }^{41}$ Taken together, these and other actions clearly indicate that the core of NATO's ability to deny Russia a victory in the Baltic Sea region hinges on its ability to rapidly move troops into the region to reinforce national and forward-deployed forces.

40 "Fact Sheet NRF 2020," JFC Brunssum; Ulrich Kühn, "Preventing Escalation in the Baltics: A NATO Playbook," Carnegie Endowment for International Peace, 2018, https://carnegieendowment.org/2018/03/28/preventing-escalation-in-baltics-nato-playbook-pub-75878.

41 "Press Conference by NATO Secretary General Jens Stoltenberg Following the Meeting of NATO Defence Ministers," NATO, October 24, 2019, https://www. nato.int/cps/en/natohq/opinions_169936.htm. 

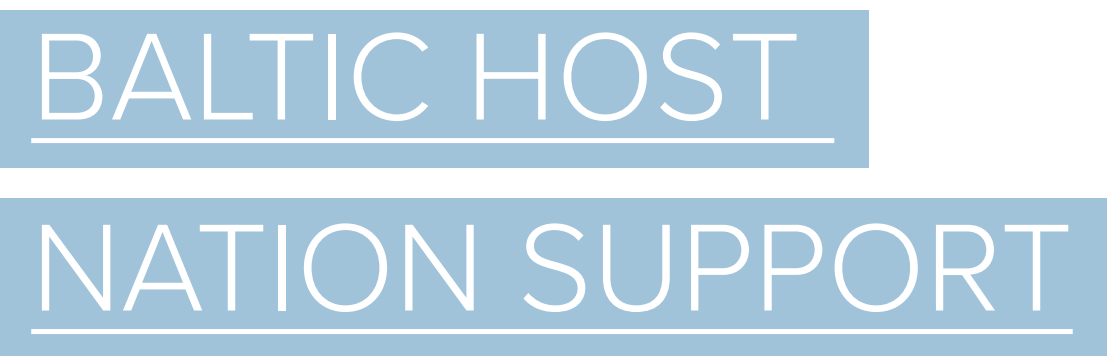

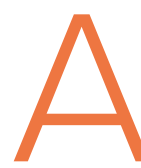
$\mathrm{s}$ the preceding discussion makes clear, the Lithuanian, Latvian, and Estonian militaries-while all capable fighting forces-lack the size, resources, and national capabilities to deter Russian aggression independent of other NATO partners. Recognizing this, especially since Russia's aggression against Europe in 2014, NATO has instituted measures such as Baltic Air Policing, the NATO eFP, and more frequent national US rotational deployments to support and augment the capabilities of the Baltic allies. Many of these activities have been enabled, in part, by increased US investment in the region through EDI. Key among the capabilities brought as part of these rotational deployments are main battle tanks and fighter aircraft that augment the credibility of the national military forces in the region, especially in response to a conventional Russian attack. The presence of multinational forces also serve to guarantee a multinational response in the case of aggression in the region.

To fulfill their mission of defense and credibly deter Russian aggression, NATO and US deployments must be supported by adequate HNS. The barracks, training ranges, maintenance facilities, transport logistics, and all other aspects of HNS provided by the Baltic states allow these small states access to critical capabilities and firepower that would normally be outside of their reach financially. All three Baltic states have invested significantly in their HNS to support allied forward presence in the region, and have worked closely with NATO, the United States, and the European Union (EU) to continually improve the infrastructure in their respective countries, even outside the bounds of normal defense spending counted by NATO.

The emphasis that the Baltic states have placed on improving their HNS-and, specifically, their infrastructure-over the last several years has been instrumental to enabling eFP and more frequent US rotations, each of which brings additional capabilities to the region. Even with substantial funding support from the United States and NATO, executing all of the infrastructure improvements detailed above has not come cheaply for the Baltic states. All three countries are estimated to have spent an above-average portion of their 2020 defense budgets on infrastructure compared to the rest of NATO, and have been consistently high spenders (especially Latvia and Estonia) over the last seven years. ${ }^{42}$ Part of the explanation for this high spending is the need to modernize legacy Soviet military infrastructure, but it is also a result of the importance of modern and capable military bases and support facilities to enhancing deterrence. Without the proper facilities, the critical, high-end capabilities brought to the region by eFP, Baltic Air Policing, and US rotations would be incapable of fulfilling their missions. Deployed forces in the region would exhaust readiness, undercutting their presence in the region as less capable and less credible deterrents against aggression. By investing in the necessary support-and-sustainment infrastructure, the Baltic states ensure that the allied forces on their territory are able to train and maintain a high degree of readiness during rotations, strengthening their deterrent value.

\section{Lithuania: HNS State of Play}

Rotational US and allied forces enhancing deterrence in Lithuania operate out of three main installations. The military base at Rukla is home to the German-led eFP battlegroup, which is embedded with Lithuania's Iron Wolf mechanized infantry brigade. A former Soviet military town, the base contains permanent barracks, a canteen, other life-support facilities, and a logistics-support area for the Iron Wolf Brigade's and eFP battlegroup's armored and support vehicles. The base is located near the recently expanded Gaižiūnai Training Area, which offers one hundred and twenty-five square kilometers of exercise area that can accommodate up to battalion-level training, including company-level maneuver and platoon-level live-fire training. ${ }^{43}$ The training area's expansion was financed largely by support from the United States and NATO. ${ }^{44}$

Lithuania's largest training area is located east of Rukla at Pabrade. With one hundred and seventy-six square kilometers

42 On average, all NATO members are estimated to have spent approximately 3.8 percent of their total defense budgets on infrastructure in 2020 . Estonia, Latvia, and Lithuania spent 7.93 percent, 7.93 percent, and 4.87 percent, respectively. "Defence Expenditure of NATO Countries (2013-2020)," NATO PDD, press release, October 21, 2020, https://www.nato.int/nato_static_fl2014/assets/pdf/2020/10/pdf/pr-2020-104-en.pdf.

43 "Lithuanian Defence System: Facts and Trends," Ministry of National Defence of the Republic of Lithuania, 2017, http://urm.It/uploads/nato/documents/nato. pdf; "Persistent US Presence in Lithuania," Ministry of National Defence of Lithuania, nonpaper, 2020.

44 “Lithuania's army to double area of training grounds by 2022," Baltic Times, January 27, 2018, https://www.baltictimes.com/lithuania_s_army_to_double_ area_of_training_grounds_by_2022/. 
of training space, the training area can accommodate maneuver exercises up to a heavy battalion and live-fire drills at the company level. The facility also boasts the region's first urban-warfare training center, which opened in $2016 .{ }^{45}$ Germany has funded an exercising force camp at the training area to provide temporary accommodation for up to five hundred eFP soldiers training there. ${ }^{46}$

Pabrade has also been the home of US units rotating through Lithuania as part of Operation Atlantic Resolve. In 2019, the US 1st Infantry Division (Forward) cooperated closely with the Lithuanian Defense Staff and Lithuanian Land Forces to construct Camp Akvilè, a new basing facility for US units on rotational deployment. The US 1-9 CAV deployed to the camp in late 2019 through early 2020 has said that the accommodation at the camp far exceeded its expectations for an operational tour as part of Atlantic Resolve. ${ }^{47}$ The camp can accommodate up to six hundred and fifty soldiers and their equipment, and includes containerized living and office facilities, along with a paved motor pool, canteen, and gym facilities. ${ }^{48}$ The camp is located close to the firing ranges, giving forces stationed there quick and easy access to the range to improve their training and readiness. In addition to constructing Camp Akvile, Lithuania provides additional elements of HNS to US forces, including force-protection services. ${ }^{49}$ US forces are also able to access the local hospital for medical emergencies, but lack of medevac capabilities and the distance from the base to the hospital were concerning for US units. ${ }^{50}$

The third major installation used by US and allied forces in Lithuania is Šiauliai Air Base. Šiauliai has hosted NATO's Baltic Air Policing mission since its inception in 2004, and acts as an important aerial port of debarkation (APOD) for troops and supplies moving into Lithuania. It is also used to refuel cargo and transit aircraft. ${ }^{51}$

Lithuania's infrastructure as a host nation has undergone major improvements in recent years, and the Ministry of National
Defence has ambitious plans to further increase the country's capacity to host and train US and NATO forces. Among recent projects are major renovations at Šiauliai Air Base funded by the United States' European Deterrence Initiative, including the construction of a taxiway, an aircraft apron, and restoration of several buildings, including a hangar and a munitionstorage building. ${ }^{52}$ After renovations, Šiauliai will be able to accommodate up to two C-5, two C-17, and four C-130 transport aircraft, along with fourteen fighter jets and eight helicopters. ${ }^{53}$ Roads have also been improved at training sites and bases throughout the country in order to better accommodate the tanks and heavy vehicles brought by US and eFP forces. ${ }^{54}$

Rukla is also expected to see upgrades to its facilities completed in the next few years. Highlights include a new permanent logistics support area (PLSA) to replace the current temporary logistics support area by 2022, and expanded barracks to support up to two battalions and the eFP battlegroup, a total of 3,500 soldiers, by 2025 , as well as additional ammunition storage. ${ }^{55}$

Perhaps the most consequential planned development by Lithuania is a permanent basing facility at Pabrade, expected to be operational by the end of 2022. The facility is intended to serve NATO's VJTF, and is expected to be made available to US forces as well. Barracks with capacity for 2,500 soldiers are planned, along with a canteen, loading ramp, helipads, and warehouse facilities. ${ }^{56}$

\section{Latvia: HNS State of Play}

Allied and US presence in Latvia is centered around the Camp

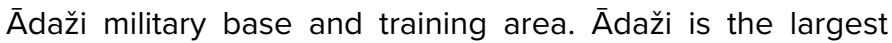
training area in the Baltic states by area and home to Latvia's NATO eFP battlegroup, as well as the headquarters of NATO's Multinational Division North. Latvia invested significantly in the life-support facilities at Ādaži before eFP's deployment in 2017, constructing four new barracks buildings at the site

\footnotetext{
45 "Lithuanian Defence System: Facts and Trends."

46 "Exercising Force Camp Is Transferred to the NATO Enhanced Forward Presence Battalion Battle Group," Ministry of National Defence Republic of Lithuania, May 29, 2018, http://kam.It/en/news_1098/current_issues/field_camp_in_transferred_to_the_nato_enhanced_forward_presence_battalion_battle_group. html.

47 Video teleconference between 1-9 CAV and project team, May 2020.

48 PowerPoint presentation during video teleconference with project team, May 2020

"Persistent US Presence in Lithuania."

Interview with 1-9 CAV command team, April 2020

“NSPA Modernises Siauliai Air Base Infrastructure under European Deterrence Initiative," NATO Support and Procurement Agency, August 13, 2020, https:// www.nspa.nato.int/news/2020/siauliai-air-base-modernisation.

52 Ibid.

53 "Persistent US Presence in Lithuania."

54 Elisabeth Braw, NATO's New Frontlines: Security and Deterrence in the Baltic Sea Region, Atlantic Council, 2016, https://www.jstor.org/stable/resrep03480.

55 PowerPoint provided by the MND to the project team.

56 Ibid.
} 
with room for up to 2,100 soldiers. ${ }^{57}$ Improvements at the site will continue in the coming years with improved fire control, vehicle-maintenance facilities, and camp security under construction as part of a three-year, $€ 50$-million investment. ${ }^{58}$

While Latvia does not host forces for the Baltic Air Policing mission, the air base at Lielvārde has played host to rotational US combat aviation forces deployed as part of Operation Atlantic Resolve. The Latvian government has invested in the air base, building new barracks facilities, vehicle parking, a new terminal building, and runway expansion. ${ }^{59}$

The training area at Camp Ādaži has already proven itself capable of hosting large multinational exercises like NATO's Saber Strike, but increased use of the facilities by national and allied units has pushed Latvia to begin expanding additional training areas elsewhere in the country. The training area at Lāčusils has seen a twenty-three-square-kilometer expansion and an upgraded shooting range, with more improvements on the way. Moreover, Meža Mackeviči regional training area acquired an additional twenty square kilometers of land from the Ministry of Agriculture. ${ }^{60}$ Expanding these training areas will reduce the stress on the facilities at Âdaži and make it easier for allied and national forces to train together, as well as provide more room for Latvia to absorb additional rotational US or allied forces and host expanded exercises. As in Lithuania, roads in and around training areas have been improved to support tanks and other military vehicles. ${ }^{61}$

\section{Estonia: HNS State of Play}

As with its two allies to the south, Estonia has also prioritized improvements to its military infrastructure and host-nation capacity in order to support increased allied presence in the country. NATO's eFP battlegroup is based at Tapa Army Base, Estonia's largest installation, located next to its Central Training Area. In 2016, Tapa received major upgrades thanks to $\$ 11.2$ million in funding from the United States' EDI (then the European Reassurance Initiative). The upgrades were intended to better enable readiness for forces stationed there, including maintenance facilities, upgraded ranges, and an improved rail-loading area. ${ }^{62}$ Despite these and other improvements, eFP forces were still being housed in temporary facilities, and

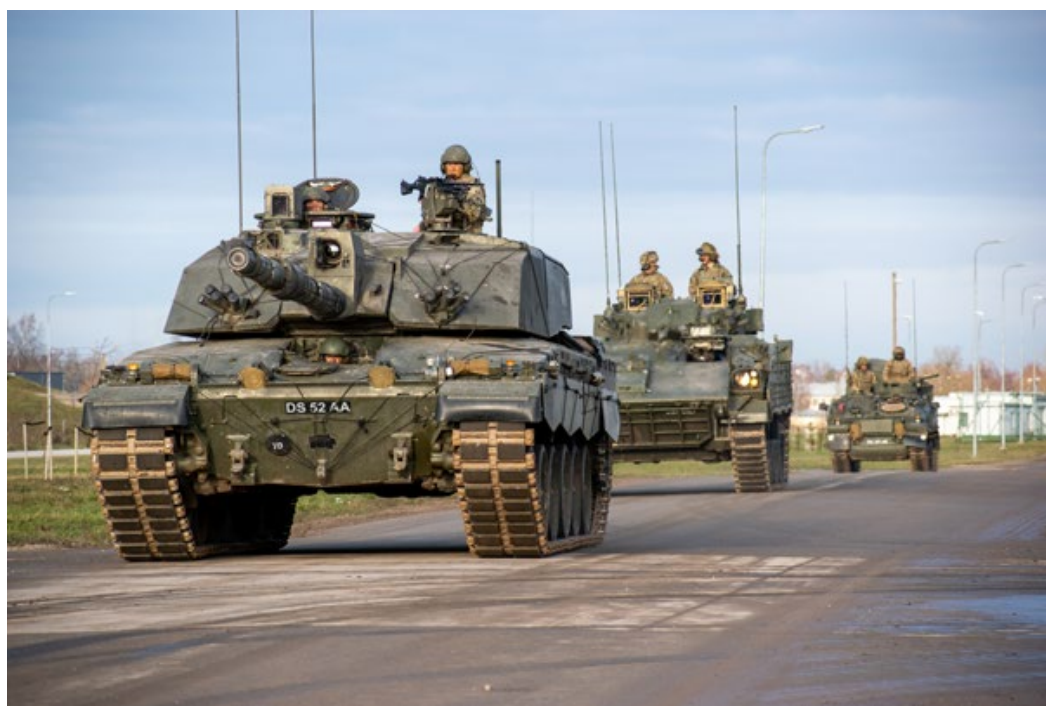

Pictured is a Challenger II of D Sqn, The Queen's Royal Hussars (QRH) leading a Warrior and Bulldog whilst conducting a readiness exercise in order to test their reaction times whilst deployed on Operation CABRIT as part of NATO's enhanced Forward Presence in Estonia. Source: Captn. Shane Charles, UK Ministry of Defence, 2020.

roads in the area had difficulty accommodating the armor and other vehicles brought by the rotating forces. To address these issues, Estonia constructed a new RSOM facility at Tapa with $€ 20$ million in funding from the NATO Security and Investment Program. Completed in 2020, the new facility consists of a brand-new assembly area with storage, accommodation, fuel management, and an expanded medical center. A brand-new road able to support heavy vehicles was also constructed between the base and the Central Training Area, to ease stress on civilian infrastructure and provide a direct route between the basing facility and training area. ${ }^{63}$

Estonia's Ämari Air Base hosts the second detachment of NATO's Baltic Air Policing mission. And, as with the facilities at Tapa, Ämari has received major improvements over the last several years to better support allied forces; $\$ 10.8$ million of EDI funding went into improvements at the base, including an expanded fighter apron that can accommodate twelve aircraft and provides increased space for large transport aircraft. ${ }^{64}$ US funds also helped to build additional barracks at Ämari after it began hosting the Baltic Air Policing Mission.

Braw, NATO's New Frontlines: Security and Deterrence in the Baltic Sea Region.

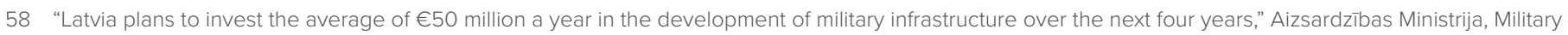
Public Affairs Department, Ministry of Defence of the Republic of Latvia, February 26, 2019, https://www.mod.gov.Iv/en/news/latvia-plans-invest-averageeu50-million-year-development-military-infrastructure-over-next.

59 Ibid

60 Ibid.

61 Braw, NATO's New Frontlines: Security and Deterrence in the Baltic Sea Region.

62 Jari Tanner, “US Military Completes \$11.2 Million Face-Lift in Estonia," Military.com, December 15, 2016, https://www.military.com/daily-news/2016/12/15/usmilitary-completes-112-million-face-lift-estonia.html.

63 "New infrastructure for hosting allied units completed in Estonia," Eesti Rahvusringhääling, June 30, 2020, https://news.err.ee/1107696/new-infrastructure-forhosting-allied-units-completed-in-estonia\#: :text=The\%20NATO\%20RSOM\%2C\%20or\%20Reception,expansion\%20of\%20the\%20medical\%20center\%2C.

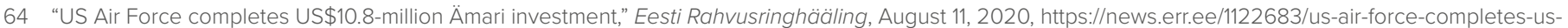
10-8-million-amari-investment. 


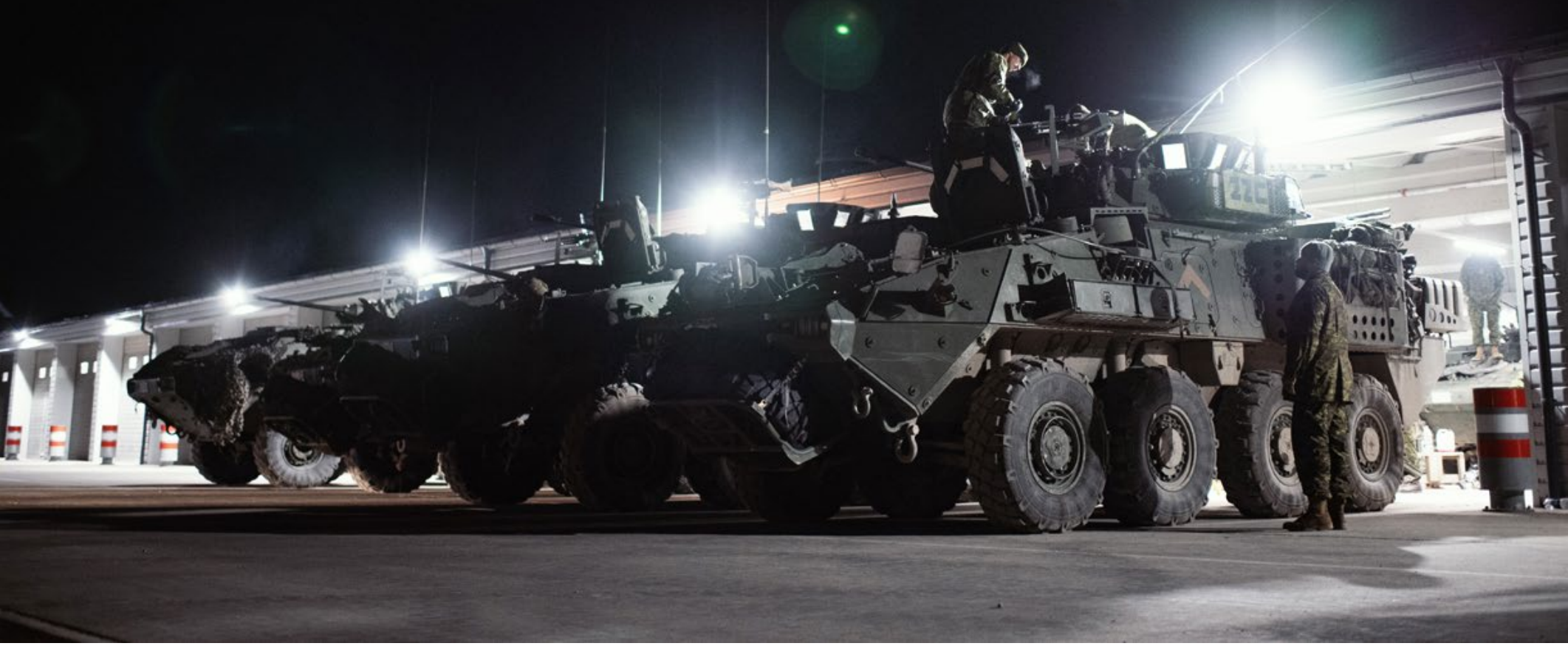

Canadian Armed Forces members deployed with enhanced Forward Presence Battle Group Latvia prepare for Exercise WINTER REAPER at Camp Ādaži, Latvia, November 25, 2019. Source: Canadian Armed Forces/Corporal Djalma Vuong-De Ramos.

\section{Baltic-Wide Efforts to Improve Mobility and HNS}

For the deterrence-by-rapid-reinforcement strategy to be effective, sufficient Baltic HNS is critical. After allied forces transit across Europe to reach the Baltic states, there must be adequate RSOM facilities, transit infrastructure, and, in some cases, prepositioned equipment available. ${ }^{65}$ Also critical are the legal procedures necessary for military personnel and equipment to quickly cross borders in the region. HNS is crucial for this reinforcement strategy to work, because "it relieves incoming forces of the burdens associated with supporting themselves and allows them to prioritise combat presence over the presence of supporting units."66 The Baltic allies recognize this, and, just as they have worked to improve the infrastructure and support services for forward-positioned allied forces, they have focused on improving their transit infrastructure and legal procedures to better enable NATO's strategy of deterrence by reinforcement.

In Lithuania, the port of Klaipeda is the country's main seaport of debarkation (SPOD) and an important ice-free SPOD for the wider region. In its current configuration, it can accommodate seven roll-on-roll-off ships simultaneously, and has vehicle wash racks and fuel available. ${ }^{67}$ The port also connects by rail to the Kaunas intermodal terminal facilitating the link-up of forces and supplies arriving by sea with those arriving by rail via Poland. The port at Klaipeda is in the early stages of a substantial expansion, and the state port authority is cooperating closely with the Ministry of National Defence to ensure that US and NATO ships are able to dock at the port and offload troops and materiel. ${ }^{68}$ Further north, Estonia's new RSOM facility at Tapa is a prime example of the HNS needed to receive and support large numbers of transiting allied troops. Latvia and Lithuania could look to this facility as a model for additional installations in their country to improve their own RSOM capabilities.

The Baltic governments have also worked to establish the proper legal authorities for rapid troop transit. A priority for Lithuania has been to streamline border-crossing procedures, and officials are now regularly able to issue transit permits for US and allied forces within twenty-four hours of a transit request. ${ }^{69}$ Latvia has instituted delayed customs procedures for non-Schengen personnel participating in amphibious or airdrop landings, and Estonia grants yearlong customs approval for specific military transit and equipment, giving forces more flexibility in their movements. ${ }^{70}$ Similar procedures in France can take up to sixty days. That the Baltic states have

\footnotetext{
65 For an in-depth examination of military mobility in Europe, see: Curtis M. Scaparrotti, et al., Moving Out: A Comprehensive Assessment of European Military Mobility, Atlantic Council, April 2020, https://www.atlanticcouncil.org/wp-content/uploads/2020/04/Moving-Out_Military-Mobility-Web.pdf.

66 Ben Hodges, Tony Lawrence, and Ray Wojcik, Until Something Moves-Reinforcing the Baltic Region in Crisis and War, Center for European Policy Analysis, International Centre for Defence and Security, April 2020, https://cepa.org/cepa_files/2020-CEPA-report-Until_Something_Moves.pdf.

67 "Persistent US Presence in Lithuania."

68 Presentation by the Klaipeda Port Authority to Atlantic Council fact-finding delegation, May 2019.

69 "Persistent US Presence in Lithuania."

70 Hodges, et al., Until Something Moves.
} 
been able to smooth the processes as much as they have demonstrates the level of effort put into easing transit into the region as much as possible.

\section{Baltic HNS Shortcomings}

Despite the important work that has already been done across the Baltic region, difficulties remain that could hamper NATO's ability to rapidly reinforce the region in the event of a crisis. First, while improvements have been made to existing roads throughout the region, in many cases the quality of roads remains hit or miss, and there are questions about the availability of infrastructure throughout the region to support heavy equipment, such as tanks. As in the rest of Europe, maintenance of civilian and dual-use infrastructure has not necessarily been adequately funded, leading to disrepair. This is compounded by the fact that much of the infrastructure in the Baltic Sea region, if it was constructed with military purposes in mind, was only built to the specifications needed to support the relatively lighter Soviet equipment from the Cold War era. ${ }^{71}$ Furthermore, there is a shortage of the heavy-equipment transporters needed to facilitate rapid road marches for tracked vehicles on public roads..$^{72}$ Flatbed railcars, too, are in short supply. ${ }^{73}$

Perhaps the most prominent obstacle to rapid reinforcement to the Baltic states is the need for allied forces and equipment traveling by rail from Poland to Lithuania and beyond to transfer from the standard-gauge railcars used in most of Europe to the wider Russian gauge still in use in the Baltic states. Lithuania has invested in new ramps and infrastructure at the Šeštokai railway terminal that has sped up railcar transfers, but the need for troops and supplies to halt and transfer still costs time that could be precious in a crisis situation. ${ }^{74}$

A partial solution to this problem is underway through the Rail Baltica project, which is constructing a standard-gauge rail line connecting Warsaw in Poland all the way to Tallinn in Estonia. The line is slated to connect to three multimodal terminals-one in each country-connecting the line to cargo arriving by air and sea. The project is funded by both the EU and contributions from the Baltic states themselves as part of the EU's broader Trans-European Transport Network (TEN-T) project. Construction is underway in all three Baltic states. ${ }^{75}$

When it is complete, Rail Baltica will be a major improvement to mobility within the Baltic states, but it will not be an end solution to the gauge-transfer problem faced by reinforcements traveling by rail. Because it is mostly a single route, allied

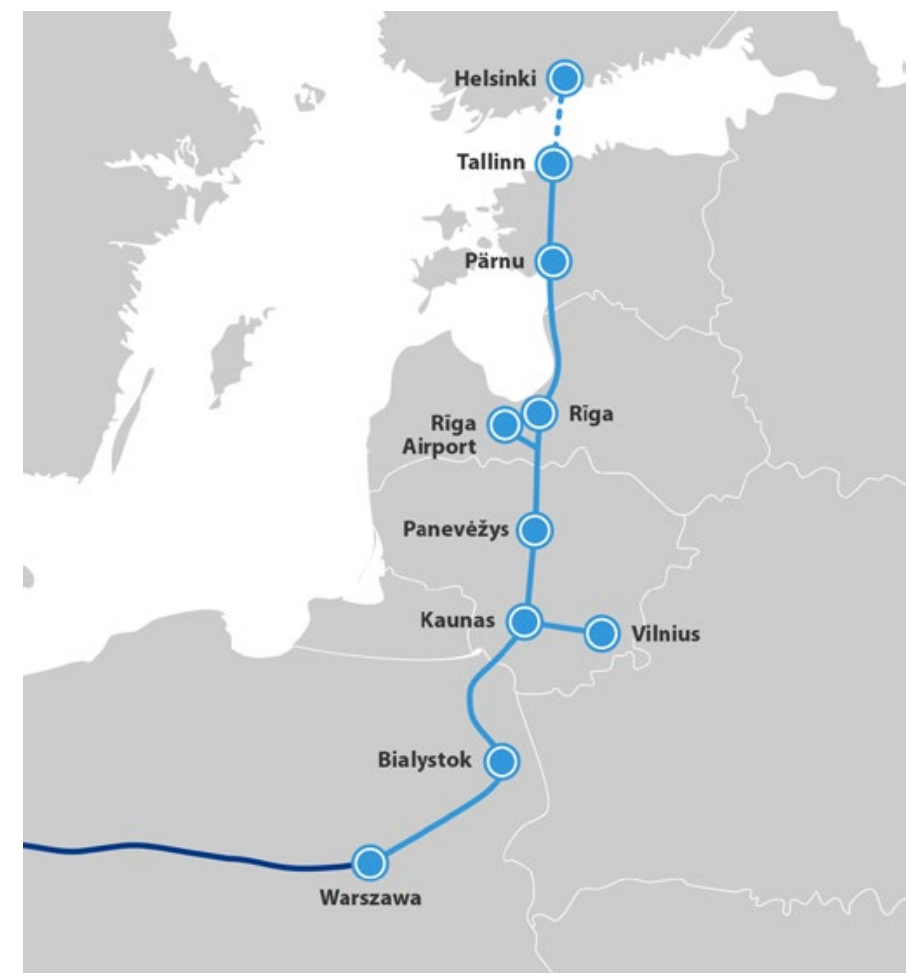

Map of the Rail Baltica European gauge rail line, currently under construction. Source: RB Rail AS/Wikimedia Commons.

troops and equipment traveling onward by rail will still need to transfer to Russian-gauge cars at some point to reach their end destinations. This will still result in slower transit, which could be costly in a crisis situation (see the Options section).

Rail Baltica is also a prime example of the difficulty in ascribing deterrent value to aspects of HNS, particularly mobility infrastructure. Rail Baltica's primary purpose is as a civilian cargo and passenger connection between the Baltic states and the rest of the EU. Similar to shipping ports, roads, and other dual-purpose infrastructure, Rail Baltica has military value in spite of the fact that the resources for developing this infrastructure are not always reflected in defense-spending figures or in conversations around burden sharing. Indeed, awareness is growing that civilian mobility infrastructureroads, rail lines, and other related services that are primarily civilian in nature until such time as a crisis emerges-ought to be factored into burden-sharing calculations. Given that HNS is a critical component of any deterrence posture, it is reasonable that it should counted as a component of NATO burden sharing.

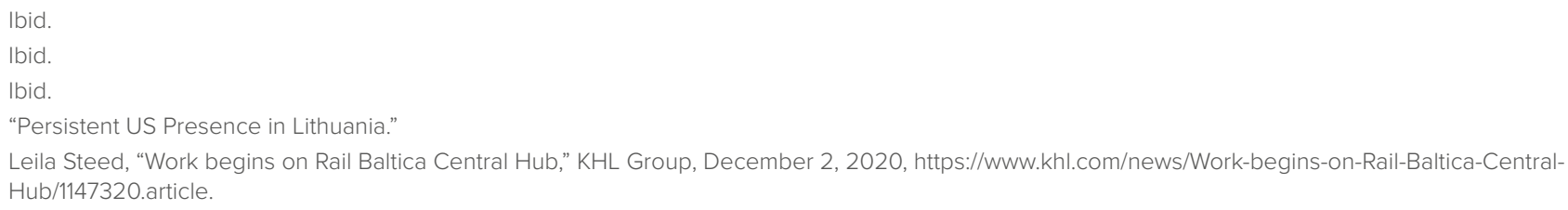



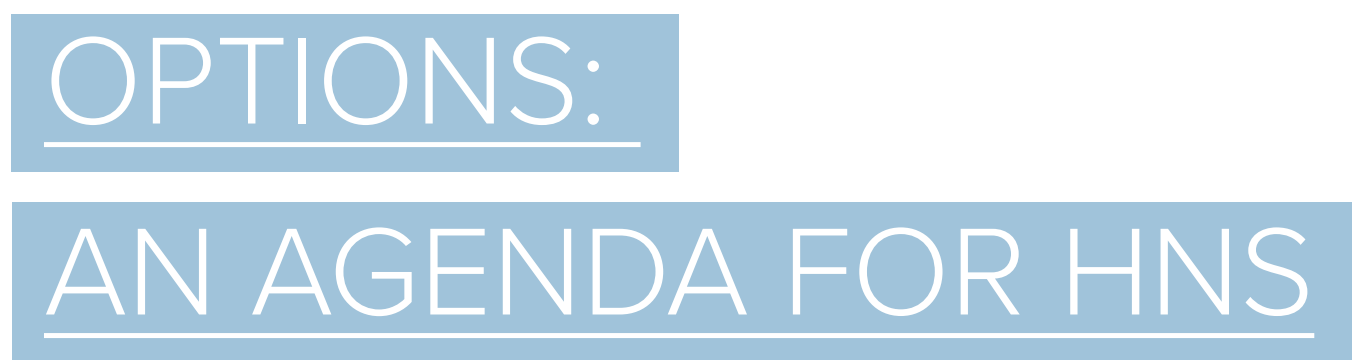

in NS is a critical element of deterrence in the Baltic Sea region. Accordingly, Lithuania, Latvia, and Estonia have undertaken serious efforts to improve their ability to provide HNS to US and NATO forces in their countries. Yet, despite the progress thus far, there is ample room for improvement on all sides. The following recommendations include ideas for the Baltic States, NATO, and the United States to work better together in ensuring expectations for HNS are clear and realistic.

\section{Action Item One: Exercising HNS}

Rotating forces in and out of the Baltics is, by design, an exercise of HNS and mobility capabilities. To that extent, rotational forces have proven a useful "stress test" of these enabling capabilities up to the battalion level, and should, therefore, be continued on a regular basis. However, large-scale testing of HNS in the region has not taken place, and the many improvements in infrastructure and procedures made by the Baltic states have not been tested under pressure. This was one of the goals of the fullscale Defender 20 exercise. However, due to adjustments because of the COVID-19 pandemic, this test did not take place at its full extent.

Exercising HNS was a crucial aspect of allied presence in Europe during the Cold War, and strengthened the credibility and capability of NATO's ability to defend Western Europe by frequently demonstrating the Alliance's ability to reinforce Europe. The same consideration should be given to HNS in the Baltic Sea region. It follows that if NATO allies want to "stress test" HNS, they might consider the following.

- Maintain current deployments of US and allied forces to the region that provide critical deterrent power in the form of high-end capabilities and clear signals of commitment. These deployments, including those as part of Operation Atlantic Resolve and NATO eFP, should be regularly assessed to determine if current capability levels are sufficient to maintain deterrence in the region and, if not, what additional capabilities and HNS would be required.
- Plan regular, large-scale reinforcement exercises in the Baltic Sea region on the scale of Defender 20. Particular attention should be paid to the Baltic states' ability to conduct RSOM operations, and any strains on infrastructure and transit procedures.

Apart from these large-scale exercises, the VJTF could regularly practice short-notice, rapid deployments to the Baltic Sea region to test the Baltic states' ability to receive this spearhead force as if it were a crisis situation.

\section{Action Item Two: Improve HNS Guidance}

In interviews conducted for this study, the team found that US assessments of Baltic HNS are very favorable. However, interviewees from the region commented that HNS requirements-specifically those from the United Statesoften came with a compressed timeline. Due to the small size of their militaries and state resources, the Baltic states typically employ private contractors to execute certain HNS functions such as construction. Proper legal procedures need to be followed when hiring these contractors, which can take up to six months in Lithuania, for example. However, requirements often come into the country with a one-to-two-month timeframe to execute, putting additional stress on their systems.

When possible, allied forces should give more advanced notice of HNS requirements for upcoming deployments to allow national authorities to better prepare and engage with the proper local resources who will execute those requirements. The more specific the requirements sent to the host nations, the better.

The Baltic states themselves should work to anticipate the needs of rotating forces by regularly soliciting feedback from outwardly rotating US and NATO forces on their perceptions of the HNS provided in their host nations. Lessons from these surveys can then be taken into account proactively when providing HNS for follow-on deployments. 


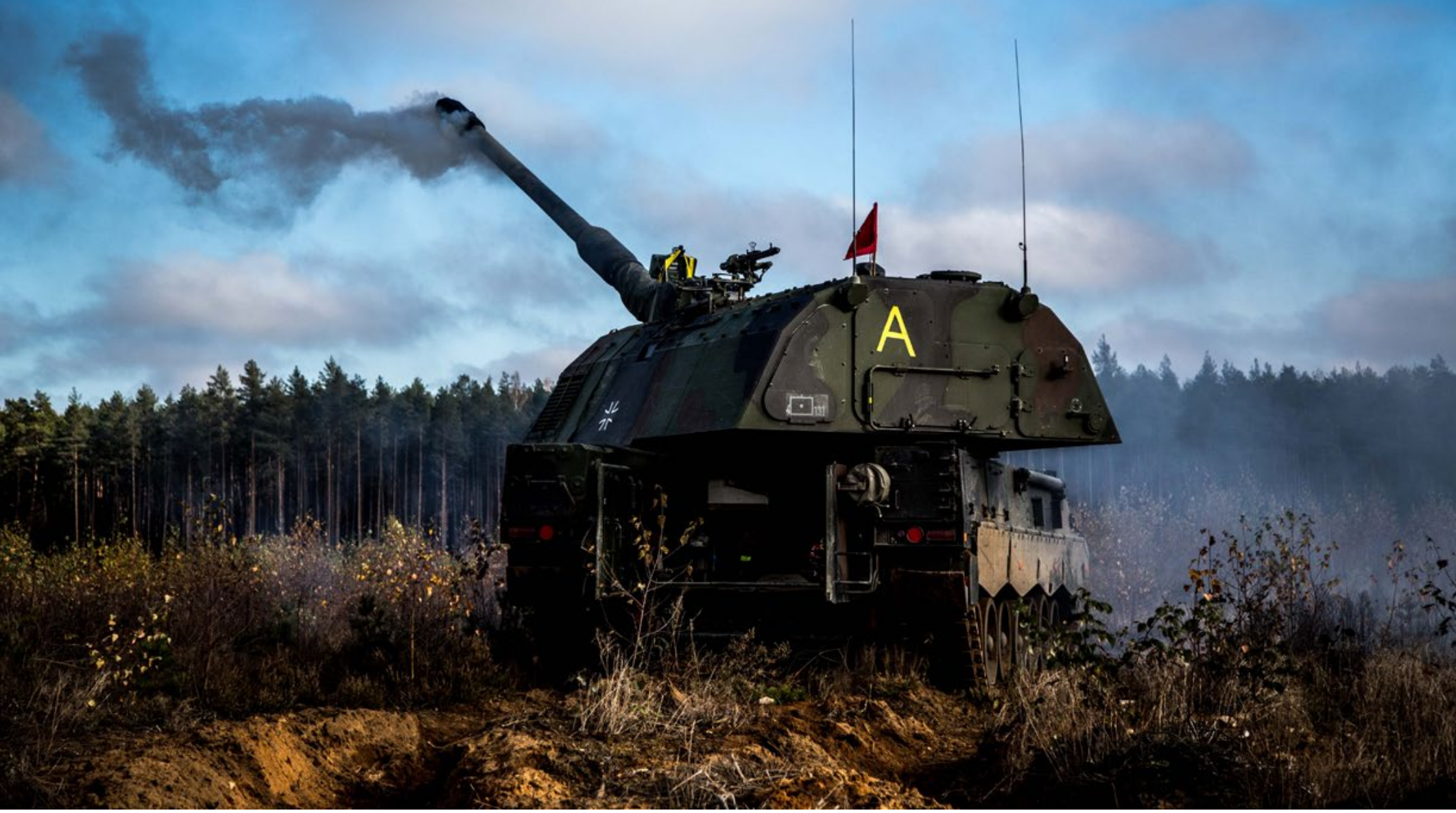

A German Panzerhaubitze 2000 (PzH 2000) during exercise Iron Wolf II in Lithuania (2017). The Lithuanian-led exercise helped train the NATO Battlegroup which consists of soldiers from Germany, Belgium, Luxembourg, the Netherlands and Norway. Shot in Pabrade, Lithuania. Source: NATO.

- For additional deterrence assets not yet rotating through the Baltic states as part of US or NATO rotations such as air-defense systems or additional special-forces units, the Baltic states should undertake preliminary planning to determine what additional HNS would be needed to support these kinds of units in the event of their deployment.

\section{Action Item Three: Regional Coordination}

The Baltic states cooperate closely in a number of areas related to defense and security, including HNS. All three states annually participate in the Baltic Host exercise to test coordination between different civilian and military actors in HNS. Despite this cooperation, there is no in-depth coordination of HNS across the three Baltic states, meaning that allies working with the three countries have to manage three different approaches to different aspects of HNS. This can inhibit bilateral relationships, such as with the United States, as well as the relationship with NATO. The three NATO Force Integration Units (NFIUs) all deal with different procedures and different approaches by each country, leaving their roles in coordinating HNS between the host nations and arriving forces somewhat murky. ${ }^{76}$ The Baltic states' collective border with Russia is about the size of West Germany's border with East Germany during the Cold War, meaning that three different systems are operating in an area small enough for one. If Baltic allies alongside NATO wish to improve regional coordination, the following actions should be taken. 
- The Baltic states could prioritize development of a common, synchronized HNS strategy applicable across all three countries. Establishing such a common strategy will allow for smoother coordination between the Baltic states and their allies, therefore making it easier for HNS requirements to be met throughout the theater. The United States and NATO could consult with the Baltic states in this process, to ensure that the resulting strategy meets expectations for HNS from the sending nations.

- A common Baltic HNS strategy could prioritize HNS for intra-Baltic mobility of eFP and US units in the event of a crisis.

- NATO could better clarify the roles and responsibilities of the three independent NFIUs, to ensure that they are properly utilized by the Baltic states. For broader coordination across the region, the creation of a Balticwide NFIU with responsibility for the Baltic states as a unified theater should be considered.

\section{Action Item Four: Continue Infrastructure Improvements}

As detailed in this paper, the Baltic states in recent years have undertaken immense efforts to improve both the support and mobility infrastructure utilized by US and NATO forces in the region. Even as additional infrastructure improvements are already underway, there are still additional steps the Baltic states could take to enhance their ability to support and transport forces, including, but not limited to the following.

\section{Mobility Improvements}

- All three Baltic states might usefully invest in standardgauge spur lines connecting the forthcoming Rail Baltica main line with key military bases and likely staging areas. These spur lines would improve the speed and ability of allied forces coming from Western Europe to reinforce deterrence without having to change trains. Connecting standard-gauge rail lines to multimodal ports in each country will also improve the ability to transfer equipment coming by sea and air to bases and staging areas.

As a long-term priority, replacing all Russian-gauge rail lines with standard gauge should be considered, potentially with financial support from the EU.

Roads in and around training and staging areas should continue to be reinforced to accommodate heavy vehicles. The ability of roads and bridges throughout the Baltic states to accommodate heavy vehicles should be assessed in order to ensure speedy movement throughout the region in a crisis scenario.

\section{Training-Range Improvements}

- The Baltic states should continue to improve and expand the training ranges in their respective countries, with a goal of replicating the facilities available in Germany. Priorities should include heated targets on shooting ranges and forward-looking infrared (FLIR) cameras on range towers to allow for better observation and assessment.

The Three Seas Initiative should be considered as a potential funding source for these and other HNS investments. ${ }^{77}$ The United States could also direct EDI funds toward similar projects.

\section{Action Item Five: Further Develop Joint HNS}

Much of the thought and effort being put into HNS in the Baltic Sea region right now has been land-centric, focused on improving facilities and training opportunities for the landbased eFP and rotating US armored and mechanized units. However, any future battles will necessarily be undertaken by a joint force across domains. NATO has proven its ability to do so through exercises like Saber Strike and Baltic Operations (BALTOPS), but additional steps can be taken to more easily facilitate reception of a joint force in the region. HNS planners should, therefore, give further consideration to how host nations can prepare to receive additional allied air, cyber, and naval assets in a crisis. Exercising the transition of Baltic Air Policing to an air-defense mission could be one way to test this ability in the air domain. ${ }^{78}$

Hodges, et al., Until Something Moves.

Kalev Stoicescu and Pauli Järvenpää, “Contemporary Deterrence: Insights and Lessons from Enhanced Forward Presence,” RKK/ICDS, January 28, 2019, https://icds.ee/en/contemporary-deterrence-insights-and-lessons-from-enhanced-forward-presence/. 


\section{CONCLUSION}

As the Biden administration reconsiders US troop presence in the Baltic Sea region as part of its global posture review, a key question before decision-makers on both sides of the Atlantic is how to best enable a credible strategy of deterrence by rapid reinforcement. The military geography of the region means that the "time-space challenge" is formidable and necessitates the development of creative solutions that enable NATO allies, including the United States, to rapidly flow key capabilities into theater in the event of a crisis. Viewed in this light, effective Host Nation Support becomes a strategically critical enabler; without well-planned and practiced HNS, NATO's ability to defend its eastern flank would undoubtedly be subject to significant risk.

Yet the conceptualization and organization of such support is in itself a challenge that ought not be understated. Somewhat different to the "light footprint" logistics that the United States and other NATO allies established to conduct global contingency operations in the past, in the case of the Baltics, the United States must be able to depend upon a presence that is light in peacetime but capable of rapidly absorbing and integrating significant numbers of conventional forces and irregular-warfare capabilities during a crisis. Discerning the pressure and friction points that might hamper such a rapid flow of forces into the region will take dedicated, sustained time and effort.

Fortunately, progress has been made in recent years toward building HNS capabilities across the Baltic states that better enable a concerted, forward presence of US and allied forces and provide necessary infrastructure to implement deterrence by rapid reinforcement strategy. Military infrastructure improvements, training-area expansion, and regional coordination are several areas in which the Baltic states have invested in order to facilitate the flow of NATO forces into the region in the event of a crisis, and to boost the readiness of allied forces stationed there to improve deterrence in peacetime. Yet, areas for improvement remain; the Baltic states might usefully consider hardening their roads to permit heavy vehicle traffic and fully moving toward EU-standard rail infrastructures to ensure that key equipment can be rapidly fielded where and when needed. To best ensure these capabilities are crediblethat is, demonstrably ready and able to respond in a crisisNATO might consider designing and executing large-scale exercises that test the Baltic states' RSOM capabilities. Greater advance notice of HNS requirements by NATO states would assist host-nation states providing necessary day-to-day support. Finally, developing common strategies and frameworks for HNS across the Baltic states might reduce possibilities of friction points emerging as sending states flow their forces and capabilities into the region.

Although it is generally thought of as a practical and tactical construct, in the context of the Baltic states, Host Nation Support is an essential enabler of NATO's posture: deterrence by rapid reinforcement simply will not work without highly capable HNS. Viewed in this light, focusing upon and prioritizing HNS investment by both NATO allies and the Baltic states themselves is of paramount importance. Failure to do so risks allies' ability to defend against Russian aggression and, therefore, might risk the strategic insolvency of NATO itself. 


\section{ACKNOWLEDGEMENTS}

The authors would like to thank the following individuals for their review and input, which greatly strengthened this paper. The conclusions and analysis in this report are those of the authors alone and do not necessarily reflect the views of the individuals listed below:

Hans Binnendijk, Distinguished Fellow, Transatlantic Security Initiative, Scowcroft Center for Strategy and Security, Atlantic Council

John R. Deni, Nonresident Senior Fellow, Transatlantic Security Initiative, Scowcroft Center for Strategy and Security, Atlantic Council

\section{ABOUT THE AUTHORS}

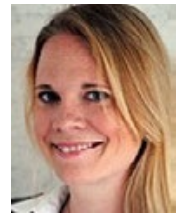

\section{Kathleen J. Mclnnis}

Nonresident Senior Fellow, Transatlantic

Security Initiative and Forward Defense, Scowcroft Center for Strategy and Security, Atlantic Council

Dr. Kathleen J. Mclnnis is a nonresident senior fellow with the Scowcroft Center for Strategy and Security's Transatlantic Security Initiative and Forward Defense practice area. Previously she was a research consultant at Chatham House in London, working on NATO and transatlantic security matters. In 2010, she co-founded Caerus Associates, a strategic design consulting firm, and served as its Chief Operating Officer until 2011. Dr. Mclnnis also served in the Office of the Secretary of Defense (Policy), working NATO-Afghanistan matters and stability operations capability development. In that capacity, she helped formulate and support US policy for two NATO summits, eight NATO Defense Ministerial meetings, and four Regional Command- South Ministerial meetings. Prior to joining Stability Operations, Dr. McInnis spent several years at the Center for Strategic and International Studies (CSIS), analyzing US nuclear weapons strategy, strategic capabilities, NATO, European security, and transatlantic relations. Before joining CSIS, she was a researcher in the United Kingdom (UK) House of Commons, working on NATO, the European Union, and US-UK political-military relations. Kathleen has commented on international affairs on television, radio, and print. She has appeared on CNN, Sky News, BBC, Al Jazeera English, and Voice of America. Her articles have featured in publications including The Atlantic Monthly, Defense One, Foreignpolicy.com, The Washington Quarterly, Defense News, War on the Rocks and The Washington Times, and was a contributing author to several Chatham House and CSIS studies. She was awarded her MSc in international relations from the London School of Economics in 2002 and completed her PhD in the Department of War Studies, King's
Marta Kepe, Nonresident Senior Fellow, Transatlantic Security Initiative, Scowcroft Center for Strategy and Security, Atlantic Council

Wayne Schroeder, Nonresident Senior Fellow, Transatlantic Security Initiative, Scowcroft Center for Strategy and Security, Atlantic Council

Jim Townsend, Adjunct Senior Fellow, Center for a New American Security

College London in 2017. Her book on coalitions, How and Why States Defect from Contemporary Military Coalitions, was published by Palgrave in 2019. Kathleen is also the author of novel, The Heart of War: Misadventures in the Pentagon (Post Hill Press, 2018). She is also a contributing author to the edited volume Strategy Strikes Back: What Star Wars Teaches Us About Modern Military Conflict, released by Potomac Press in April 2018.

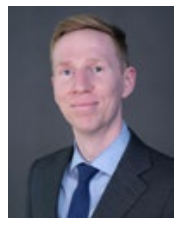

\section{Connor McPartland Assistant Director Transatlantic Security Initiative, Scowcroft Center for Strategy and Security, Atlantic Council}

Connor McPartland is an assistant director with the Atlantic Council's Transatlantic Security Initiative where he assists in operationalizing the Scowcroft Center's programming related to NATO and European security issues. His work at the Council has focused on the future of the transatlantic air domain, Baltic Sea regional security, and China's impact on transatlantic relations. Originally from Florissant, Missouri, Connor graduated Phi Beta Kappa from the University of lowa with a Bachelor of Arts in International Relations and German in 2015. During his time at the University of lowa he spent a year studying at Albert-Ludwigs-Universität Freiburg where he focused on German politics, history, and linguistics. He received his Master of Public Policy from the University of Minnesota's Humphrey School of Public Affairs in 2018. His work has been published by the Atlantische Initiative and Law \& Liberty. Prior to joining the Council, Connor worked as a research intern with the Hudson Institute's Center for Political-Military Analysis, as a graduate teaching assistant at the Humphrey School of Public Affairs, and as a legislative aide with the Office of the Revisor of Statutes at the Minnesota Legislature. 


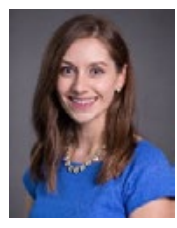

\section{Clementine G. Starling \\ Deputy Director, Forward Defense; \\ Fellow, Transatlantic Security Initiative, Scowcroft Center for Strategy and Security Atlantic Council}

Clementine G. Starling is the deputy director of Forward Defense and resident fellow of the Transatlantic Security Initiative at the Atlantic Council. In her role, she oversees the Initiative's programming and research, and leads on the defense policy and European security practice areas. Her own research focuses on great power competition with China and Russia, deterrence and US force posture, and transatlantic security. During her time at the Council, Starling has produced and contributed to reports on Russia's nuclear strategy, military mobility, political warfare, Europe-China relations, and the US-UK relationship. Starling's analysis has been featured in a range of publications and she has provided commentary for National Public Radio, the BBC, and ABC News, among others. Within the Transatlantic Security team, she played a leading role in managing NATO's official public diplomacy efforts ("NATO Engages") around the Alliance's 2019 London Leaders' Meeting and other summits. Starling is also the Security and Defense fellow at Young Professionals in Foreign Policy (YPFP). Prior to joining the Atlantic Council, Starling worked in the UK Parliament with the House of Commons Defence Select Committee providing analysis on UK defense, Middle East security, and technology. Originally from the United Kingdom, she also worked for the Britain Stronger in Europe (BREMAIN) campaign. She graduated with honors from the London School of Economics with a Bachelor of Science in International Relations and History.

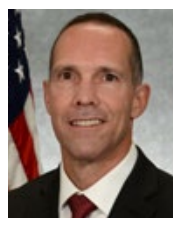

David Millner

CEO and Co-Founder

AlD Partners, LLC

David Millner currently serves as a civilian in the Department of the Navy and as an independent consultant, having previously served nearly thirty years in the US Army, retiring as a Colonel. In the Army, David spent the majority of his career as a political/military affairs specialist focused on Russia, Eastern Europe, and Central Asia, and served in a broad range of command and staff positions in the fields of operations, strategic policy, human intelligence, diplomacy, and arms control. David's key assignments included director for the Baltic Region in the Office of the Secretary of Defense (Policy), chief of Russian De-Confliction for Coalition operations in Syria, chief of Nuclear Arms Control Implementation at the Defense Threat Reduction Agency, director of VIP Security for the International Security Assistance Force in Afghanistan, and senior defense official/defense attaché in Lithuania. He has developed and implemented US defense policy, executed sensitive intelligence operations, led contentious arms control inspections, and conducted diplomatic engagements and international negotiations. David is a graduate of the United States Military Academy at West Point and earned master's degrees from Harvard University and the US Army War College. Through years of study, travel, and international service, David has developed proficiency in the Russian, German, French, and Lithuanian languages, and he has been recognized with numerous awards from the US and foreign governments 


\section{Atlantic Council Board of Directors}

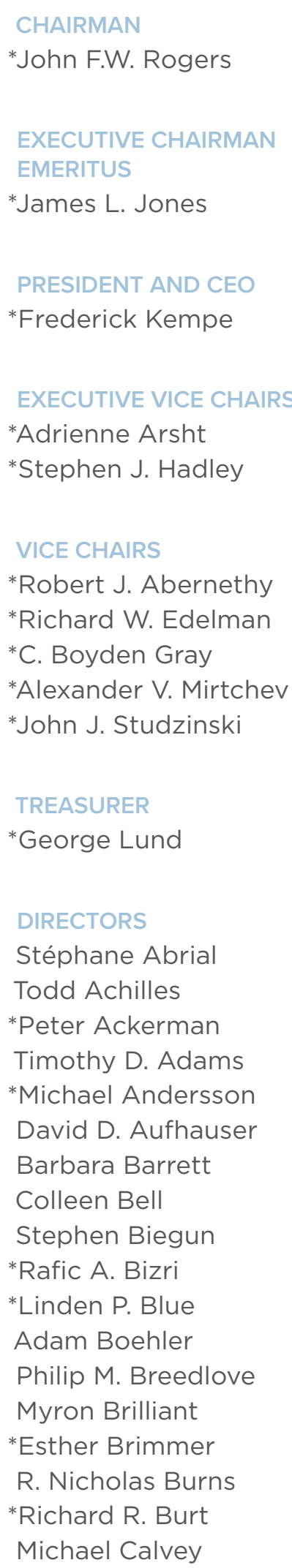

Teresa Carlson

James E. Cartwright

John E. Chapoton

Ahmed Charai

Melanie Chen

Michael Chertoff

*George Chopivsky

Wesley K. Clark

Beth Connaughty

*Helima Croft

Ralph D. Crosby, Jr.

*Ankit N. Desai

Dario Deste

*Paula J. Dobriansky

Joseph F. Dunford, Jr.

Thomas J. Egan, Jr.

Stuart E. Eizenstat

Thomas R. Eldridge

Mark T. Esper

*Alan H. Fleischmann

Jendayi E. Frazer

Courtney Geduldig

Meg Gentle

Thomas H. Glocer

John B. Goodman

*Sherri W. Goodman

Murathan Günal

Amir A. Handjani

Frank Haun

Michael V. Hayden

Amos Hochstein

*Karl V. Hopkins

Andrew Hove

Mary L. Howell

Ian Ihnatowycz

Wolfgang F. Ischinger

Deborah Lee James

Joia M. Johnson

* Maria Pica Karp

Andre Kelleners

Henry A. Kissinger

${ }^{*}$ C. Jeffrey Knittel

Franklin D. Kramer

Laura Lane
Jan M. Lodal

Douglas Lute

Jane Holl Lute

William J. Lynn

Mark Machin

Mian M. Mansha

Marco Margheri

Chris Marlin

William Marron

Gerardo Mato

Timothy McBride

Erin McGrain

John M. McHugh

H.R. McMaster

Eric D.K. Melby

*Judith A. Miller

Dariusz Mioduski

*Michael J. Morell

*Richard Morningstar

Georgette Mosbacher

Dambisa F. Moyo

Virginia A. Mulberger

Mary Claire Murphy

Edward J. Newberry

Thomas R. Nides

Franco Nuschese

Joseph S. Nye

Ahmet M. Ören

Sally A. Painter

Ana I. Palacio

*Kostas Pantazopoulos

Alan Pellegrini

David H. Petraeus

W. DeVier Pierson

Lisa Pollina

Daniel B. Poneman

*Dina H. Powell

McCormick

Robert Rangel

Thomas J. Ridge

Lawrence Di Rita

Michael J. Rogers

Charles O. Rossotti

Harry Sachinis
C. Michael Scaparrotti

Ivan A. Schlager

Rajiv Shah

Kris Singh

Walter Slocombe

Christopher Smith

Clifford M. Sobel

James G. Stavridis

Michael S. Steele

Richard J.A. Steele

Mary Streett

*Frances M. Townsend

Clyde C. Tuggle

Melanne Verveer

Charles F. Wald

Michael F. Walsh

Gine Wang-Reese

Ronald Weiser

Olin Wethington

Maciej Witucki

Neal S. Wolin

*Jenny Wood

Guang Yang

Mary C. Yates

Dov S. Zakheim

HONORARY DIRECTORS

James A. Baker, III

Ashton B. Carter

Robert M. Gates

James N. Mattis

Michael G. Mullen

Leon E. Panetta

William J. Perry

Colin L. Powell

Condoleezza Rice

Horst Teltschik

John W. Warner

William $\mathrm{H}$. Webster

*Executive Committee Members

List as of April 30, 2021 


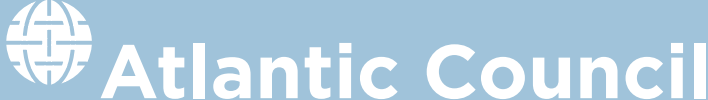

The Atlantic Council is a nonpartisan organization that promotes constructive US leadership and engagement in international affairs based on the central role of the Atlantic community in meeting today's global challenges.

(c) 2021 The Atlantic Council of the United States. All rights reserved. No part of this publication may be reproduced or transmitted in any form or by any means without permission in writing from the Atlantic Council, except in the case of brief quotations in news articles, critical articles, or reviews. Please direct inquiries to:

Atlantic Council

1030 15th Street, NW, 12th Floor. Washington, DC 20005

(202) 463-7226, www.AtlanticCouncil.org 